Article

\title{
Curcumin Attenuates Adipogenesis by Inducing Preadipocyte Apoptosis and Inhibiting Adipocyte Differentiation
}

\author{
Liang-Yi Wu ${ }^{1,+}{ }^{\circ}$, Chien-Wei Chen ${ }^{2,3,+}$, Luen-Kui Chen ${ }^{2}$, Hsiang-Yun Chou ${ }^{2}$, \\ Chih-Ling Chang ${ }^{2}$ and Chi-Chang Juan ${ }^{2,4, *}$ \\ 1 Department of Bioscience Technology, College of Science, Chung-Yuan Christian University, \\ Chung Li 32023, Taiwan; lywu@cycu.edu.tw \\ 2 Department of Physiology, School of Medicine, National Yang-Ming University, Taipei 11221, Taiwan; \\ gogozipper130@gmail.com (C.-W.C.); luenkui0506@gmail.com (L.-K.C.); convey07@hotmail.com (H.-Y.C.); \\ forrest70312@gmail.com (C.-L.C.) \\ 3 College of Human Development and Health, National Taipei University of Nursing and Health Sciences, \\ Taipei 11219, Taiwan \\ 4 Department of Medical Research and Education, Taipei Veterans General Hospital, Taipei 11217, Taiwan \\ * Correspondence: ccjuan@ym.edu.tw; Tel.: +886-2-28267000 (ext. 7085) \\ $\dagger$ These authors contributed equally to this work and should be considered co-first authors.
}

Received: 19 June 2019; Accepted: 10 September 2019; Published: 28 September 2019

check for updates

\begin{abstract}
Patients with metabolic syndrome are at an increased risk of developing type 2 diabetes and cardiovascular diseases. The principal risk factor for development of metabolic syndrome is obesity, defined as a state of pathological hyperplasia or/and hypertrophy of adipose tissue. The number of mature adipocytes is determined by adipocyte differentiation from preadipocytes. The purpose of the present study is to investigate the effects of curcumin on adipogenesis and the underlying mechanism. To examine cell toxicity of curcumin, 3T3-L1 preadipocytes were treated with 0-50 $\mu \mathrm{M}$ curcumin for 24,48 , or $72 \mathrm{~h}$, then cell viability was measured using the MTT (3-(4,5-dimethylthiazol-2-yl)-2,5-diphenyltetrazolium bromide) assay. The effect of curcumin on the cell cycle was determined by flow cytometry. Curcumin-induced cell apoptosis was determined by the TUNEL assay and curcumin-induced caspase activation was measured by immunoblotting. The effect of curcumin on adipocyte differentiation was determined by measuring mitotic clonal expansion (MCE), expression of adipogenic transcription factors, and lipid accumulation. Results showed the viability of preadipocytes was significantly decreased by treatment with $30 \mu \mathrm{M}$ curcumin, a concentration that caused apoptosis in preadipocytes, as assessed by the TUNEL assay, and caused activation of caspases 8,9, and 3. A non-cytotoxic dose of curcumin $(15 \mu \mathrm{M})$ inhibited MCE, downregulated the expression of PPAR $\gamma$ and $C / E B P \alpha$, prevented differentiation medium-induced $\beta$-catenin downregulation, and decreased the lipid accumulation in 3T3-L1 adipocytes. In conclusion, our data show that curcumin can induce preadipocyte apoptosis and inhibit adipocyte differentiation, leading to suppression of adipogenesis.
\end{abstract}

Keywords: curcumin; adipocytes; adipogenesis; apoptosis; mitotic clonal expansion; differentiation

\section{Introduction}

Increased visceral fat mass is associated with the development of metabolic disorders, including insulin resistance, dyslipidemia, hypertension, atherosclerosis, and inflammation [1]. Obesity is considered as the main cause of metabolic disorders-related diseases, such as cardiovascular disease, hypertension, hyperlipidemia, type 2 diabetes, and cancer [2]. Thus, the prevention of abnormal 
adipogenesis could be an efficient strategy for preventing the development of metabolic disorder-related diseases [3,4].

Curcumin, a yellow phenolic component of turmeric, is derived from the rhizome of Curcuma longa L. and has antioxidant [5], anti-inflammation [6,7], and anti-cancer properties [8,9]. It also has several ameliorating effects on metabolic disorders. For example, dietary supplementation with curcumin significantly reduces obesity, inflammation, and diabetes in obese animal models [10-12]. Curcumin also inhibits TNF $\alpha$-stimulated inflammatory cytokine expression in adipocytes [10] and suppresses preadipocyte differentiation in vitro [13]. Supplementation with curcumin significantly reduces the high-fat diet-induced increase in body weight gain and adiposity in mice [13,14]. A similar inhibition of differentiation of 3T3-L1 adipocytes was reported by Lee et al. [15], who also found that curcumin can induce apoptosis of MCF-7 breast cancer cells; however, the apoptotic effect of curcumin on preadipocytes was not investigated. In addition, although curcumin is known to have an anti-obesity effect [10-15], little is known about the underlying mechanisms of inhibition of adipogenesis.

The adipogenic process is divided into different stages of growth arrest, mitotic clonal expansion (MCE), and differentiation. Retinoblastoma protein $(\mathrm{Rb})$, a tumor suppressor protein, plays an important role in the initial step of adipogenesis. Adipogenic hormones, such as isobutylmethylxanthine (IBMX), dexamethasone, and insulin, induce $\mathrm{Rb}$ phosphorylation through the cyclin-dependent kinase pathway, resulting in dissociation of the $\mathrm{Rb} / \mathrm{E} 2 \mathrm{~F}$ complex and allowing E2F to promote cell-cycle progression to the $S$ phase [16-18]. The next step in adipogenesis is the re-entry of growth-arrested preadipocytes into the cell cycle and the completion of several rounds of MCE. Several groups have reported that MCE is necessary for subsequent preadipocyte differentiation [19-23].

Adipocyte differentiation is a complex process that is mainly controlled by two families of transcription factors, CCAAT enhancer binding proteins (C/EBPs) and peroxisome proliferator-activated receptors (PPARs) $[24,25]$. Differentiation of preadipocytes is characterized by marked changes in the pattern of gene expression that are caused by the sequential induction of these transcription factors. Preadipocytes exposed to differentiation inducers show an early and transient increase in expression of C/EBP $\beta$ and C/EBP $\delta[26,27]$ which, in turn, contributes to cell proliferation and to the subsequent increase in expression of C/EBP $\alpha$ and PPAR $\gamma$ [28,29]. These last two proteins are thought to act synergistically in the transcriptional activation of a variety of adipocyte-specific genes, with each activating the expression of the other [30,31].

The other regulatory pathway of adipogenesis is the Wnt signaling pathway, which maintains preadipocytes in an undifferentiated state by inhibiting expression of the adipogenic transcription factors C/EBP $\alpha$ and PPAR $\gamma$ [32,33]. In 3T3-L1 adipocytes, curcumin is reported to activate phosphorylation of AMP-activated protein kinase (AMPK), thus downregulating the PPAR $\gamma$ expression, and to inhibit adipogenesis [15]. It also inhibits adipogenesis in 3T3-L1 adipocytes by restoring nuclear translocation of the Wnt signaling component $\beta$-catenin to a similar level compared to that in undifferentiated preadipocytes [34].

As aforementioned, the nutrient constituents of curcumin make it a potential candidate for the therapy of obesity. However, this possibility and underlying mechanisms remain to be proven largely. Hence, this study aims to describe the role of curcumin in the regulation of adipocyte generation and sought to elucidate the molecular mechanisms of the actions responsible.

\section{Methods and Materials}

\subsection{Experimental Design}

To explore dose and time effects of curcumin on the viability of 3T3-L1 preadipocytes, the cells were pretreated for $1 \mathrm{~h}$ with different concentration of curcumin $(0,10,15,30,50 \mu \mathrm{M})$, then incubated with differentiation medium (see below) in the continued presence of the same concentration of curcumin for different times $(0,24,48,72 \mathrm{~h})$, when cell viability was determined using the MTT assay. To further clarify the effect of curcumin on apoptosis, 3T3-L1 preadipocytes were pretreated for $1 \mathrm{~h}$ with $30 \mu \mathrm{M}$ 
curcumin, then incubated for $24 \mathrm{~h}$ with differentiation medium in the continued presence of $30 \mu \mathrm{M}$ curcumin, then apoptosis was evaluated using the TUNNEL assay. To gain an insight into the apoptosis signaling pathway involved, expression of caspase proteins was examined by immunoblotting.

To explore the effect of curcumin on adipocyte differentiation, 3T3-L1 preadipocytes were pretreated for $1 \mathrm{~h}$ with different concentrations of curcumin $(0,5,10,15,20 \mu \mathrm{M})$, then differentiation was induced by incubation for 10 days in the continued presence of the same concentration of curcumin. During the differentiation processes, MCE was measured by flow cytometry, phosphorylation or expression of adipogenic proteins ( $\mathrm{pRb}$, cyclin $\mathrm{D}_{1}, \mathrm{C} / \mathrm{EBP} \beta, \mathrm{p} 27, \mathrm{PPAR} \gamma, \mathrm{C} / \mathrm{EBP} \alpha$, and $\beta$-catenin) was measured by immunoblotting, and the efficiency of adipocyte differentiation was determined by measuring intracellular triglyceride (TG) content and by Oil red O staining.

To test whether the PPAR $\gamma$ ligand rosiglitazone reversed the inhibitory effect of curcumin on differentiation, 3T3-L1 preadipocytes were incubated for $1 \mathrm{~h}$ with or without $0.5 \mu \mathrm{M}$ rosiglitazone, then were incubated with or without $15 \mu \mathrm{M}$ curcumin in the continued presence or absence of rosiglitazone for 3 days in differentiation medium, 3 days in complete medium containing $1.7 \mu \mathrm{M}$ insulin and 3 days in complete medium. During the differentiation processes, MCE and the efficiency of adipocyte differentiation were measured.

\subsection{Cell Culture}

3T3-L1 preadipocytes (American Type Culture Collection, Rockville, MD) were seeded onto 60-mm dishes or 12-well plates (Falcon ${ }^{\circledR}$, Becton Dickinson, NJ, USA) and grown and maintained in complete medium [Dulbecco's modified Eagle's (DME) high glucose medium containing 100 units/mL of penicillin and $100 \mu \mathrm{g} / \mathrm{mL}$ of streptomycin (all from Gibco BRL, Gaithersburg, MD, USA), and 10\% fetal bovine serum (FBS) (Biological Industries, Kibbutz Beit Ha'Emek, Israel)] in $10 \% \mathrm{CO}_{2}$. The cells were grown to 3 days post-confluency, then induced to differentiate by incubation for 3 days in differentiation medium, i.e., complete medium containing $0.5 \mathrm{mM} \mathrm{IBMX}, 0.5 \mu \mathrm{M}$ dexamethasone, and $1.7 \mu \mathrm{M}$ insulin (all from Sigma, St. Louis, MO, USA), 3 days in complete medium containing $1.7 \mu \mathrm{M}$ insulin and 3 days in complete medium. The medium was then changed every 3 days until the cells were fully differentiated. Typically, by day $10,>95 \%$ of the preadipocytes had differentiated into adipocytes as determined by staining for lipid accumulation using Oil Red O. This study protocol was used in all experiments.

\subsection{Mitotic Clonal Expansion Assayed by Cell Counting or by the MTT Assay}

Using direct cell counting, cell numbers were quantified after trypsinization using a hemocytometer. Using the MTT assay, cells were seeded onto 96-well plates at approximately $1 \times 10^{3}$ cells/well in $100 \mu \mathrm{L}$ of DMEM containing $0.5 \%$ FBS. After incubation with curcumin, $15 \mu \mathrm{L}$ of 3-(4,5-dimethylthiazol-2-yl)2,5-diphenyltetrazolium bromide (MTT; USB, Amersham Life sciences, Cleveland, OH, USA) was added (final concentration $0.5 \mathrm{mg} / \mathrm{mL}$ ) for $4 \mathrm{~h}$, then $100 \mu \mathrm{L}$ of DMSO was added to dissolve the formazan crystals formed and the optical density was measured on an ELISA plate reader using test and reference wavelengths of 570 and $630 \mathrm{~nm}$, respectively.

\subsection{Propidium Iodide Staining and Flow Cytometry Analysis}

Treated cells were trypsinized, washed with phosphate-buffered saline (PBS), and fixed overnight in 75\% ethanol. The cells were washed twice with PBS and the cell pellet resuspended in cold PBS, then the cells were incubated at room temperature for 5-10 minutes with PBS containing $25 \mu \mathrm{g} / \mathrm{mL}$ of propidium iodide (PI), $0.5 \mathrm{mg} / \mathrm{mL}$ of RNase A, and $0.1 \%$ Triton X-100. The fluorescence of the PI-stained cells was measured at $570 \mathrm{~nm}$ using a Cytomics FC 500 flow cytometer (Beckman Coulter Inc., Fullerton, California, USA) and the cell cycle distribution was analyzed using Cytomics FC 500 CXP software. 


\subsection{TUNEL Assay}

DNA cleavage was verified by enzymatic end-labeling of DNA strand breaks using in situ cell death detection kits (Roche Applied Science, Indianapolis, IN) according to the manufacturer's instructions. TUNEL-positive cells were evaluated on a Cytomics FC 500 flow cytometer (Beckman Coulter Inc., Fullerton, California, USA) and the data were analyzed using Cytomics FC 500 CXP software.

\subsection{Immunoblotting}

Whole cell lysates were prepared by sonication for $10 \mathrm{sec}$ in an ice-bath in lysis buffer $(1 \%$ Triton X-100, $50 \mathrm{mM} \mathrm{KCl,} 25 \mathrm{mM}$ HEPES, pH 7.8, $10 \mu \mathrm{g} / \mathrm{mL}$ of leupeptin, $20 \mu \mathrm{g} / \mathrm{mL}$ of aprotinin, $125 \mu \mathrm{M}$ dithiothreitol, $1 \mathrm{mM}$ phenylmethylsulfonyl fluoride, $1 \mathrm{mM}$ sodium orthovanadate). Samples (30 $\mu \mathrm{g}$ of total protein) in $50 \mu \mathrm{L}$ of reducing sample buffer were boiled for $5 \mathrm{~min}$ and resolved on $12.5 \%$ SDS polyacrylamide gels for $90 \mathrm{~min}$ at 160 volts, then the proteins were transferred onto a polyvinylidene difluoride membrane for $120 \mathrm{~min}$ at 60 volts. The membrane was pre-blotted for $1 \mathrm{~h}$ at room temperature in blocking buffer (5\% skimmed milk in PBS), then incubated for $24 \mathrm{~h}$ at $4{ }^{\circ} \mathrm{C}$ with primary antibodies against caspase 8, 9, or 3 (all from Cell Signaling Technologies, Danvers, MA, USA), PPAR $\gamma, \mathrm{C} / \mathrm{EBP} \alpha$, or $\beta$-catenin (all from Santa Cruz Biotechnology, Inc., Santa Cruz, CA, USA), $\mathrm{pRb}$, cyclin $\mathrm{D}_{1}, \mathrm{C} / \mathrm{EBP} \beta, \mathrm{p} 27$, or $\beta$-actin (all from Sigma-Aldrich Corp., St. Louis, MO, USA) in blocking buffer, then for $1 \mathrm{~h}$ at room temperature with horseradish peroxidase-conjugated secondary antibody (Sigma-Aldrich Corp., St. Louis, MO, USA) in blocking buffer, followed by detection of bound antibody using chemiluminescence reagent (Amersham Biosciences, GE Healthcare, Bucks, $\mathrm{UK})$. To detect multiple signals on a single membrane, the membrane was treated with stripping buffer (59 mM Tris- $\mathrm{HCl}, 2 \% \mathrm{SDS}, 0.75 \%$ 2-mercaptoethanol) for $30 \mathrm{~min}$ at $50{ }^{\circ} \mathrm{C}$ prior to re-blotting with a different antibody.

\subsection{Triglyceride Measurement}

3T3-L1 adipocytes were homogenized by sonication and triglycerides were measured using commercial kits (DiaSys Diagnostic Systems GmbH \& Co. KG, Holzheim, Germany).

\subsection{Oil Red O Staining}

To examine the lipid accumulation, cells cultured in 12-well plates were fixed with formalin and stained with Oil Red O. To quantify Oil Red O staining, the stained cells were washed with distilled water, and, after removal of the water, $1 \mathrm{~mL}$ of isopropanol was added for $10 \mathrm{~min}$ and the optical density was measured in a plate reader at $510 \mathrm{~nm}$.

\subsection{Statistical Analysis}

Experiments were repeated four times. The results are expressed as the mean $\pm \mathrm{SD}$. Statistical significance was assessed by one way analysis of variance or Student's t-test, a value of $P<0.05$ being considered statistically significant. 


\section{Results}

\subsection{Effects of Curcumin on the Viability of 3T3-L1 Preadipocytes and Activation of Caspases}

As shown in Figure 1A, 3T3-L1 preadipocytes were pretreated for $1 \mathrm{~h}$ with different concentrations of curcumin $(0-50 \mu \mathrm{M})$, then incubated with differentiation medium in the continued presence of the same concentration of curcumin for $24 \mathrm{~h}$ (white bars), $48 \mathrm{~h}$ (gray bars), or $72 \mathrm{~h}$ (black bars) and cell viability was determined using the MTT assay, showing that cell survival was not affected by treatment with 10 or $20 \mu \mathrm{M}$ curcumin, but cell death was induced by 30 or $50 \mu \mathrm{M}$ curcumin $(P<0.05)$ and the cytotoxic effect was dose- and time-dependent. The $\mathrm{LD}_{50}$ of curcumin on preadipocyte viability is about $30 \mu \mathrm{M}$. Propidium iodide (PI) staining and flow cytometry analyses showed that $30 \mu \mathrm{M}$ curcumin caused a time-dependent accumulation of cells with DNA damage in sub-G1 phase (Figure 1B; Table 1). These results showed that high dose curcumin could induce cell death in 3T3-L1 preadipocytes. We then performed a TUNNEL assay to evaluate the apoptotic effect of $30 \mu \mathrm{M}$ curcumin on 3T3-L1 preadipocytes. As shown in Figure 2A,B, there was a significant increase in high fluorescence intensity cells in the curcumin-treated cells compared to controls after treatment for 24 or $48 \mathrm{~h}$. The quantitative data showed a 40-fold increase at $24 \mathrm{~h}$ and a 65 -fold increase at $48 \mathrm{~h}$ (Figure 2C), demonstrating that this cytotoxic dose of curcumin induced apoptosis in 3T3-L1 preadipocytes.

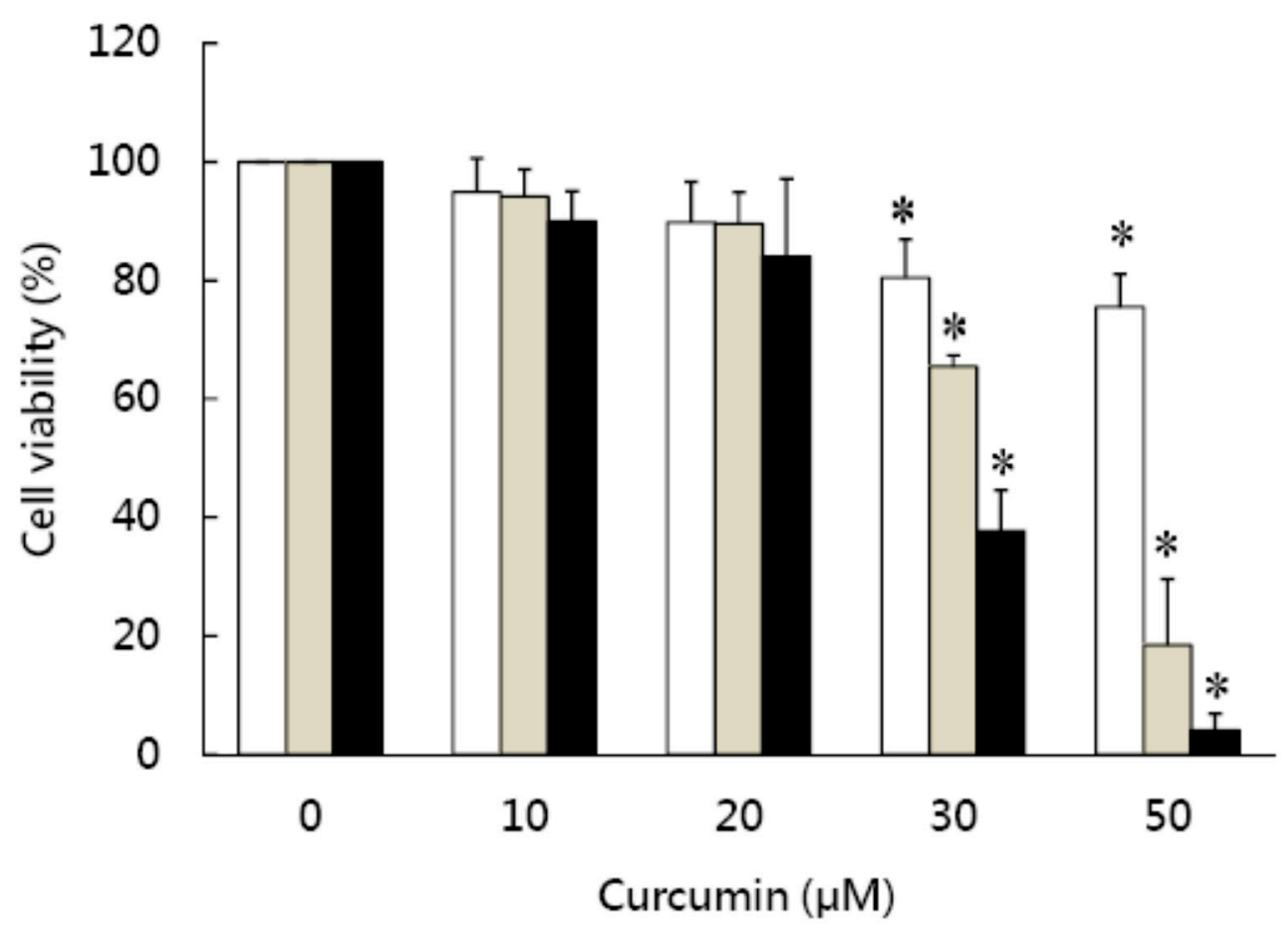

(A)

Figure 1. Cont. 


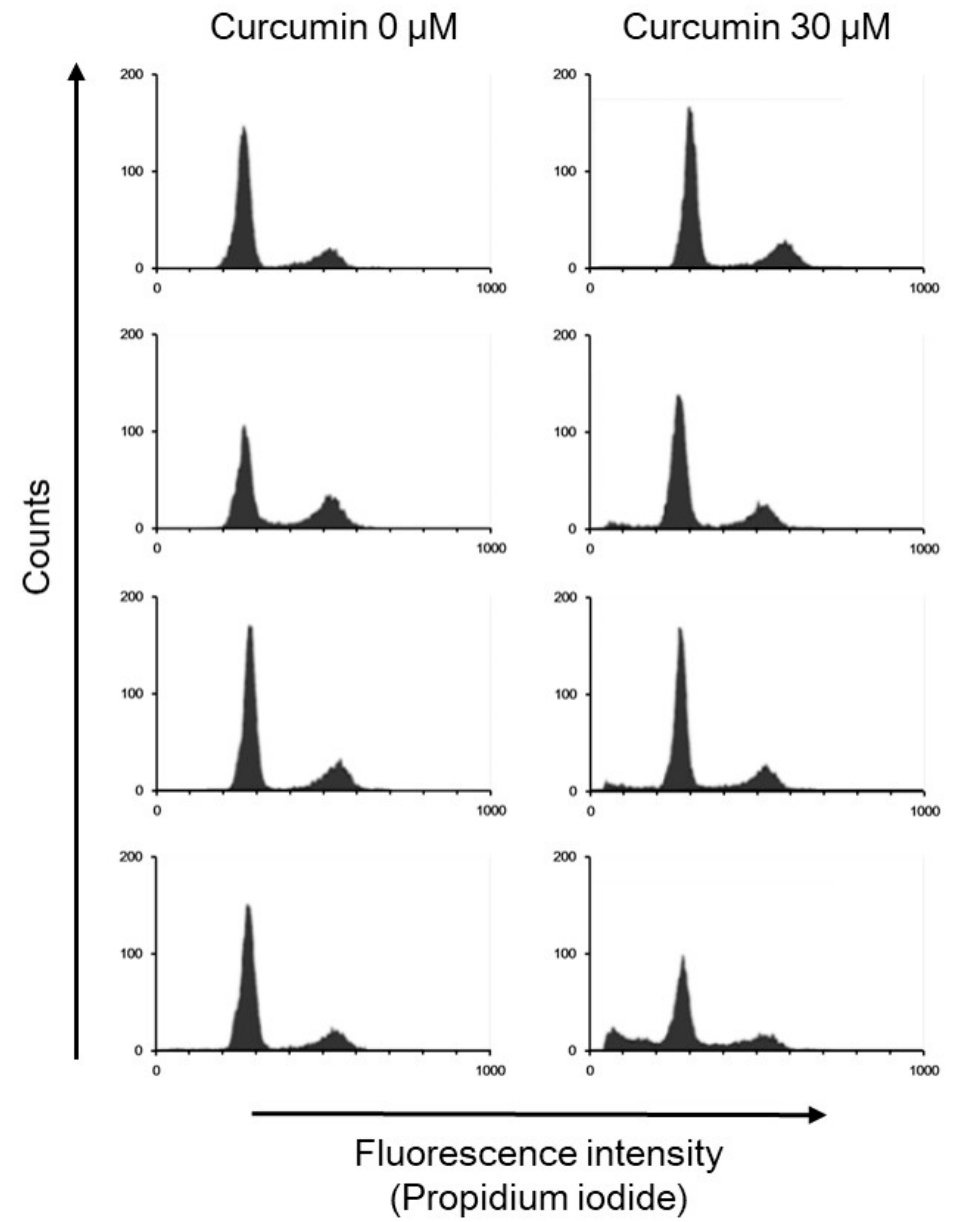

(B)

Figure 1. Effect of curcumin on the viability of 3T3-L1 preadipocytes. (A) 3T3-L1 preadipocytes were pretreated with $0-50 \mu \mathrm{M}$ curcumin for $1 \mathrm{~h}$, then were incubated with differentiation medium in the continued presence of the same concentration of curcumin for $24 \mathrm{~h}$ (white bars), $48 \mathrm{~h}$ (gray bars), or 72 $\mathrm{h}$ (black bars) and cell viability was determined using the MTT assay. The results are shown as the mean \pm SD for four independent experiments. ${ }^{*} P<0.05$ compared to the vehicle control. (B) 3T3-L1 preadipocytes were pretreated with 0 or $30 \mu \mathrm{M}$ curcumin for $0-72 \mathrm{~h}$, then the cell cycle distribution was analyzed by flow cytometry. The results shown are representative of those in four separate experiments.

Table 1. Effect of $30 \mu \mathrm{M}$ curcumin on the cell cycle of 3T3-L1 preadipocytes.

\begin{tabular}{|c|c|c|c|c|c|}
\hline & & \multicolumn{4}{|c|}{ Cell Cycle Distribution (\%) } \\
\hline & & Sub-G1 & G0/G1 & $\mathbf{S}$ & G2/M \\
\hline \multirow{2}{*}{$0 \mathrm{~h}$} & Control & $1.28 \pm 0.49$ & $75.70 \pm 5.08$ & $7.97 \pm 2.06$ & $14.56 \pm 3.98$ \\
\hline & Curcumin & $1.09 \pm 0.50$ & $74.58 \pm 5.62$ & $9.72 \pm 4.05$ & $14.20 \pm 1.54$ \\
\hline \multirow{2}{*}{$24 \mathrm{~h}$} & Control & $2.47 \pm 1.12$ & $47.72 \pm 7.28$ & $14.76 \pm 2.77$ & $34.24 \pm 7.22$ \\
\hline & Curcumin & $5.33 \pm 1.90 *$ & $70.83 \pm 4.68 *$ & $11.22 \pm 3.98$ & $12.37 \pm 1.85$ * \\
\hline \multirow{2}{*}{$48 \mathrm{~h}$} & Control & $3.88 \pm 2.86$ & $71.57 \pm 3.96$ & $7.64 \pm 1.34$ & $16.08 \pm 1.95$ \\
\hline & Curcumin & $7.36 \pm 1.16^{*}$ & $69.01 \pm 7.87$ & $9.83 \pm 3.71$ & $13.58 \pm 5.19$ \\
\hline \multirow{2}{*}{$72 \mathrm{~h}$} & Control & $4.76 \pm 1.86$ & $74.40 \pm 3.77$ & $7.56 \pm 2.27$ & $12.85 \pm 1.81$ \\
\hline & Curcumin & $18.41 \pm 5.65$ * & $60.83 \pm 9.65$ & $10.31 \pm 2.94$ & $10.22 \pm 1.70$ \\
\hline
\end{tabular}

The activation of caspases is the critical stage in cell apoptosis. To examine the role of caspases in apoptosis induced by curcumin in 3T3-L1 preadipocytes, activation of caspase-8, caspase-9, and 
caspase-3 was examined after $24 \mathrm{~h}$ treatment with $30 \mu \mathrm{M}$ curcumin. As shown in Figure $2 \mathrm{D}$, curcumin treatment significantly increased the levels of the proteolytically activate forms of caspase-8, caspase-9, and caspase-3. These data suggest that both the intrinsic (caspase-9) and extrinsic (caspase-8) apoptotic pathways are involved in the cytotoxic effects of curcumin.

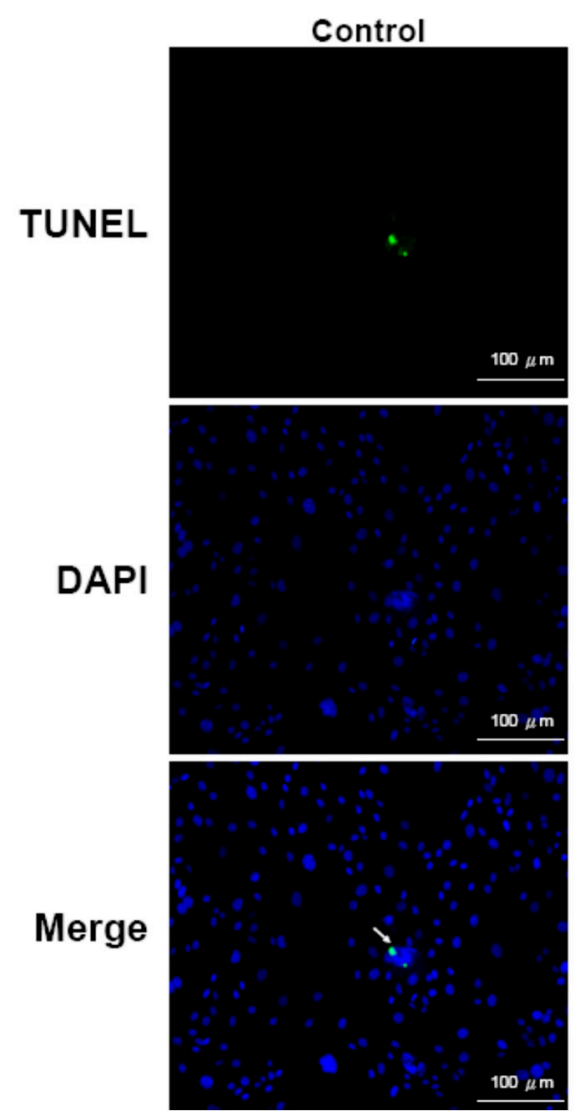

(A)
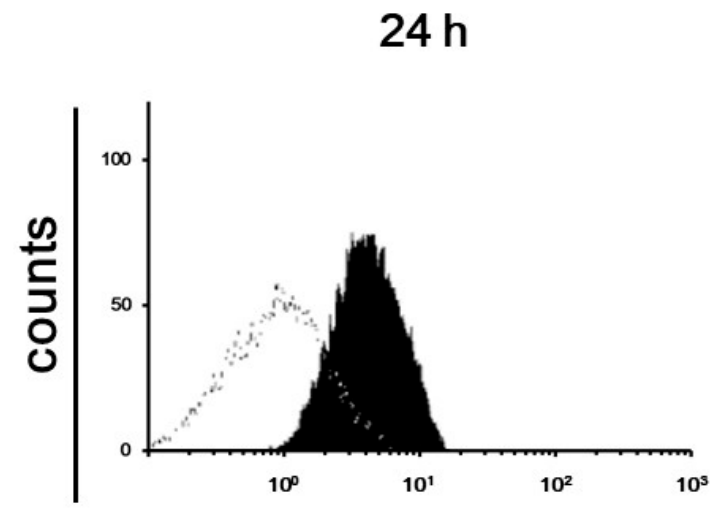

Curcumin

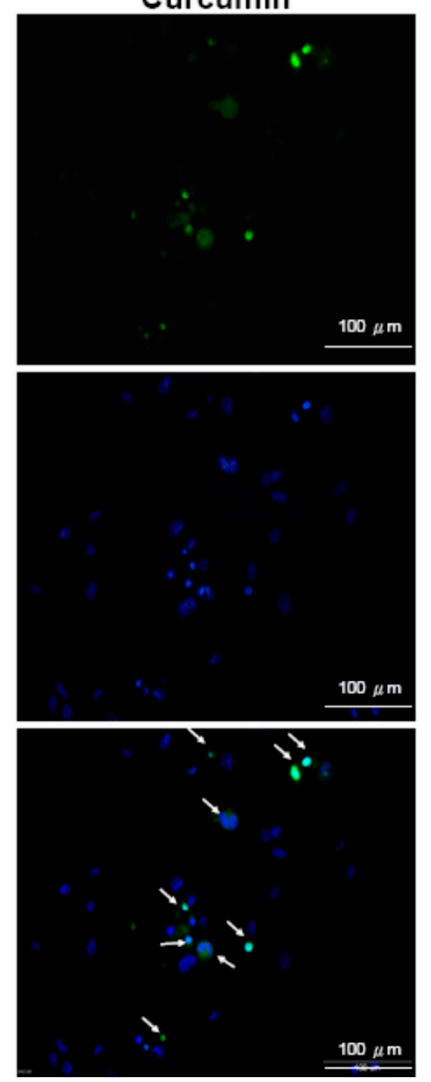

$48 \mathrm{~h}$

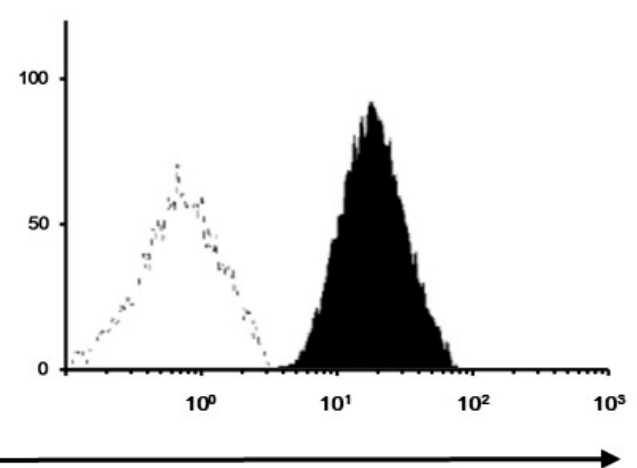

Fluorescence intensity

(B)

Figure 2. Cont. 


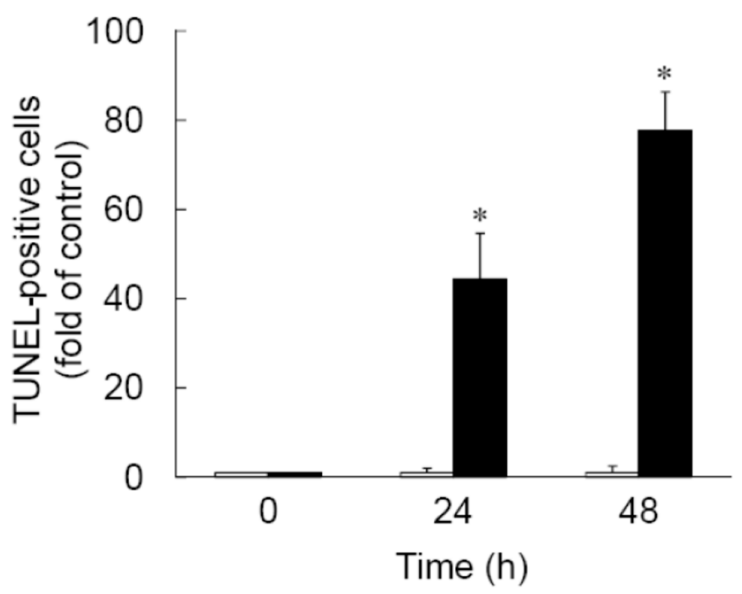

(C)

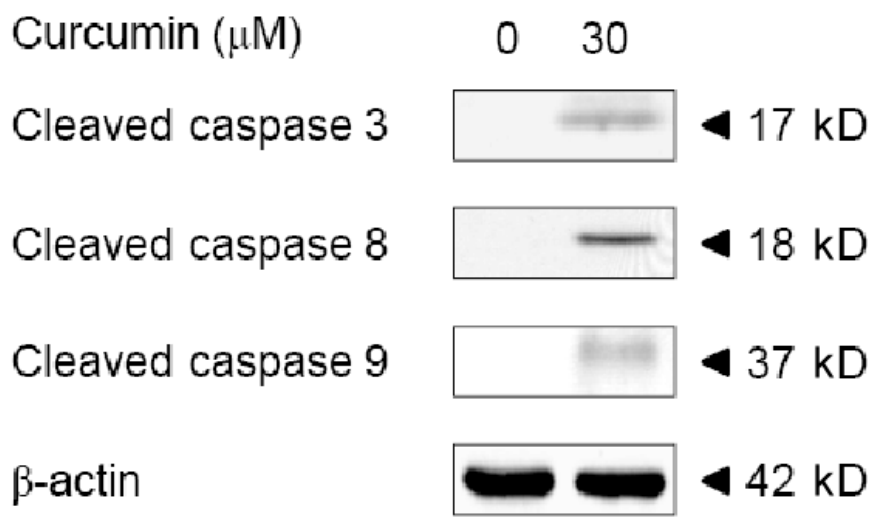

(D)

Figure 2. High-dose curcumin induces apoptosis in 3T3-L1 preadipocytes. (A-C) 3T3-L1 preadipocytes were left untreated $(\square)$ or were incubated with $30 \mu \mathrm{M}$ curcumin $(\boldsymbol{\square})$ for 24 (B-C) or $48 \mathrm{~h}(\mathbf{B}, \mathbf{C})$, then cell apoptosis was examined by TUNEL staining (blue fluorescence DAPI staining of nuclei and green fluorescence TUNEL staining of apoptotic cells) (A) and quantified by flow cytometry (B,C). (D) Western blots of cleaved caspase 3, 8, and 9 in 3T3-L1 preadipocytes after 24-h incubation in medium alone or medium containing $30 \mu \mathrm{M}$ curcumin. In (A,B,D), the results shown are representative of those in four separate experiments. In $(\mathbf{C})$, the results are the mean \pm SD for four independent experiments. * $P<0.05$ compared to the vehicle control.

\subsection{Low Dose Curcumin Inhibits Adipogenesis in 3T3-L1 Adipocytes in a Dose-Dependent Manner}

Since the cell viability study showed that low dose $(\leq 20 \mu \mathrm{M})$ curcumin did not affect the viability of 3T3-L1 preadipocytes (Figure 1A), we investigated the effect of low dose curcumin on adipocyte differentiation. 3T3-L1 preadipocytes were incubated alone or with 5, 10, 15, or $20 \mu \mathrm{M}$ curcumin for $1 \mathrm{~h}$, then adipocyte differentiation was induced in the continued presence or absence of the same concentration of curcumin for 9 days, then the intracellular triglyceride content and Oil red $\mathrm{O}$ staining were measured to evaluate the efficiency of differentiation. As shown in Figure 3A, curcumin lowered the intracellular triglyceride content in a dose-dependent manner. Furthermore, results of Oil red O staining revealed that $15 \mu \mathrm{M}$ curcumin significantly inhibited the accumulation of lipid droplets in 3T3-L1 adipocytes (Figure 3B) and this was confirmed by quantitative analyses (Figure 3C). These results show that low dose curcumin has an anti-adipogenic effect on adipocyte differentiation. 


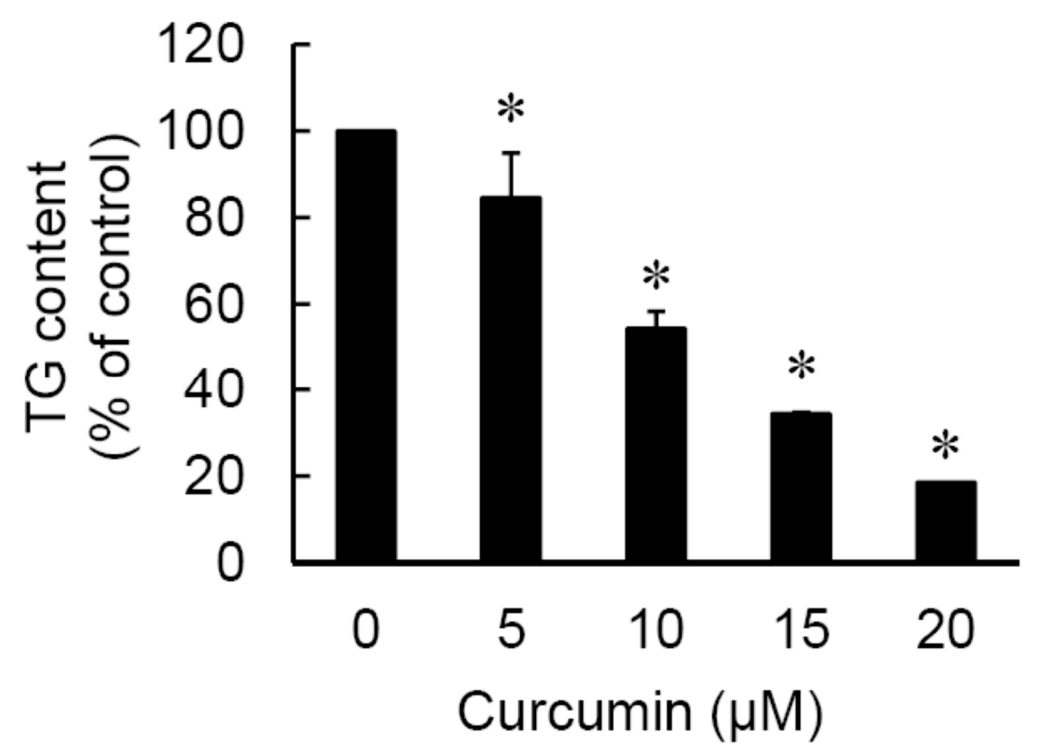

(A)

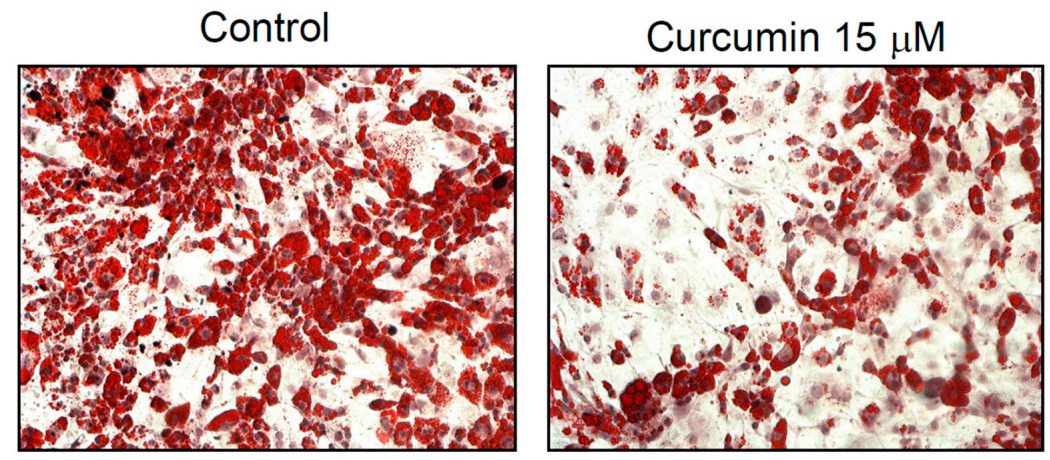

(B)

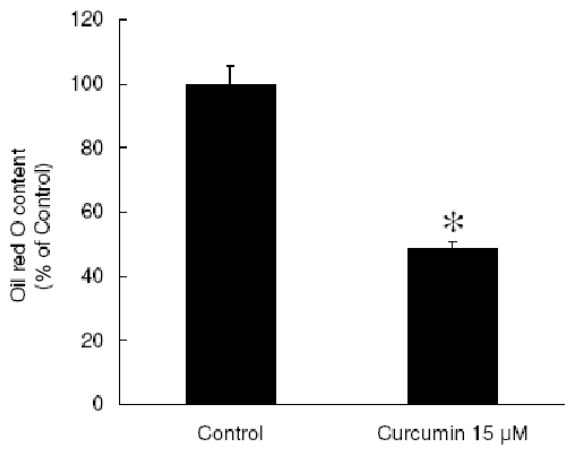

(C)

Figure 3. Low dose curcumin inhibits adipogenesis in 3T3-L1 adipocytes. 3T3-L1 preadipocytes were pretreated for $1 \mathrm{~h}$ with different concentrations of curcumin $(0,5,10,15,20 \mu \mathrm{M})(\mathrm{A})$ or with $15 \mu \mathrm{M}$ curcumin $(\mathbf{B}, \mathbf{C})$, then adipocyte differentiation was induced in the continued presence of the same concentration of curcumin. At the end of differentiation, the intracellular lipid content was determined by measuring triglyceride (TG) $(\mathbf{A})$ and Oil red $\mathrm{O}$ staining $(\mathbf{B}, \mathbf{C})$. In $(\mathbf{A}, \mathbf{C})$, the results are the mean \pm SD for four independent experiments. ${ }^{*} P<0.05$ compared to the vehicle control. The results shown in (B) are representative of those in four separate experiments. 
3.3. Effect of Low Dose Curcumin on Mitotic Clonal Expansion in 3T3-L1 Cells During the Early Stage of Adipocyte Differentiation

First, we explored the effect of $15 \mu \mathrm{M}$ curcumin on MCE, a necessary step in adipocyte differentiation [19,21-23]. MCE of 3T3-L1 preadipocytes following induction of differentiation was found to be significantly decreased by curcumin treatment, as shown by direct cell counting (Figure 4A) or the MTT assay (Figure 4B). Flow cytometry analyses showed that untreated differentiating cells entered the $\mathrm{S}$ phase and the subsequent G2/M phase transition after $24 \mathrm{~h}$ of induction of adipocyte differentiation and were rearrested in G0/G1 phase of the cell cycle after $48 \mathrm{~h}$ of induction of adipocyte differentiation (Figure 1B, Table 2). However, treatment with $15 \mu \mathrm{M}$ curcumin delayed the S phase entry and the subsequent G2/M phase transition and resulted in an increased number of cells arrested in G0/G1 phase after $24 \mathrm{~h}$ of induction of adipocyte differentiation (Figure 1B, Table 2). In addition, curcumin $(15 \mu \mathrm{M})$-treated differentiating cells were not rearrested in G0/G1 phase after $72 \mathrm{~h}$ of induction of adipocyte differentiation (Table 2). To elucidate the molecular mechanism involved in curcumin-induced delayed cell-cycle entry, we explored the effect of $15 \mu \mathrm{M}$ curcumin on the cell-cycle regulators by examining phosphorylation of $\mathrm{Rb}$ and the expression of cyclin $\mathrm{D} 1, \mathrm{C} / \mathrm{EBP} \beta$, and P27 Kip1. Figure 5A shows a typical result and Figure 5B-E shows the summarized results for each protein. Curcumin treatment significantly decreased $\mathrm{Rb}$ phosphorylation in differentiating cells after $8 \mathrm{~h}$ of induction of adipocyte differentiation (Figure 5B) and significantly decreased cyclin D1 expression after $12 \mathrm{~h}$ and $16 \mathrm{~h}$ of induction (Figure 5C). The expression of the Cdk inhibitor P27Kip1 was significantly increased in curcumin-treated differentiating cells after $8 \mathrm{~h}$ and $12 \mathrm{~h}$ of induction of adipocyte differentiation (Figure 5D). There was no difference on expression of C/EBP $\beta$ between the two groups (Figure 5E).

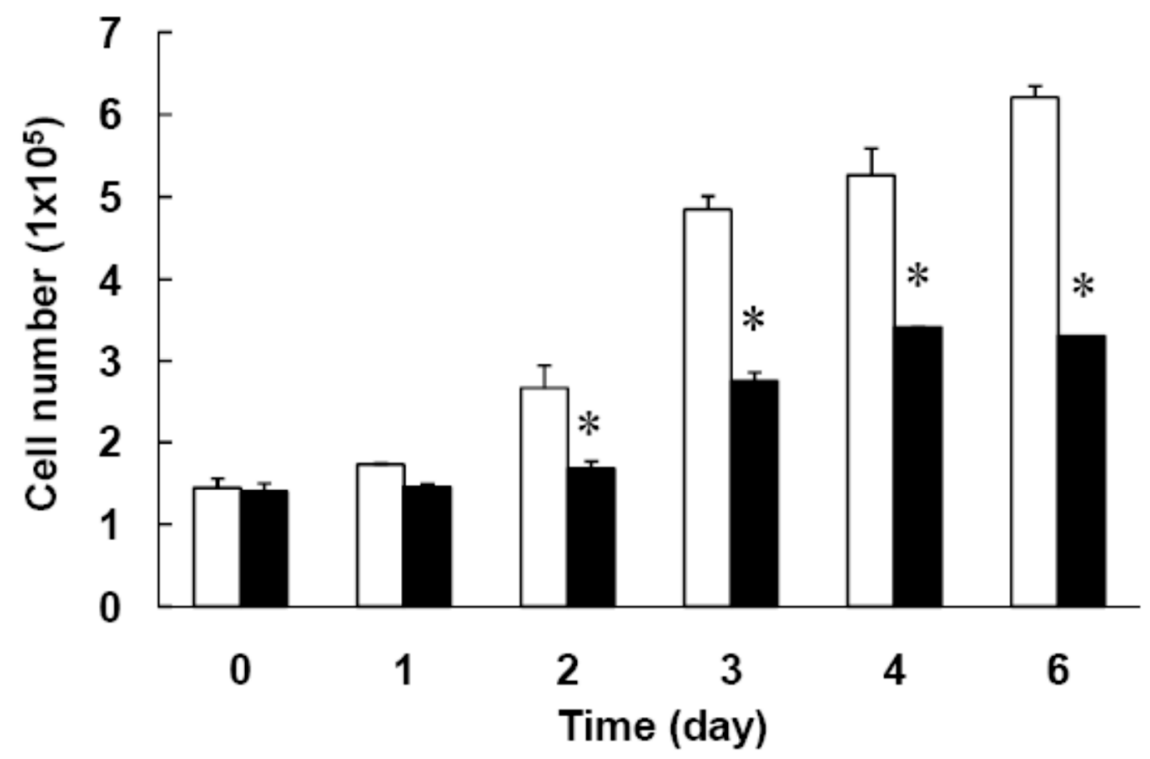

(A)

Figure 4. Cont. 


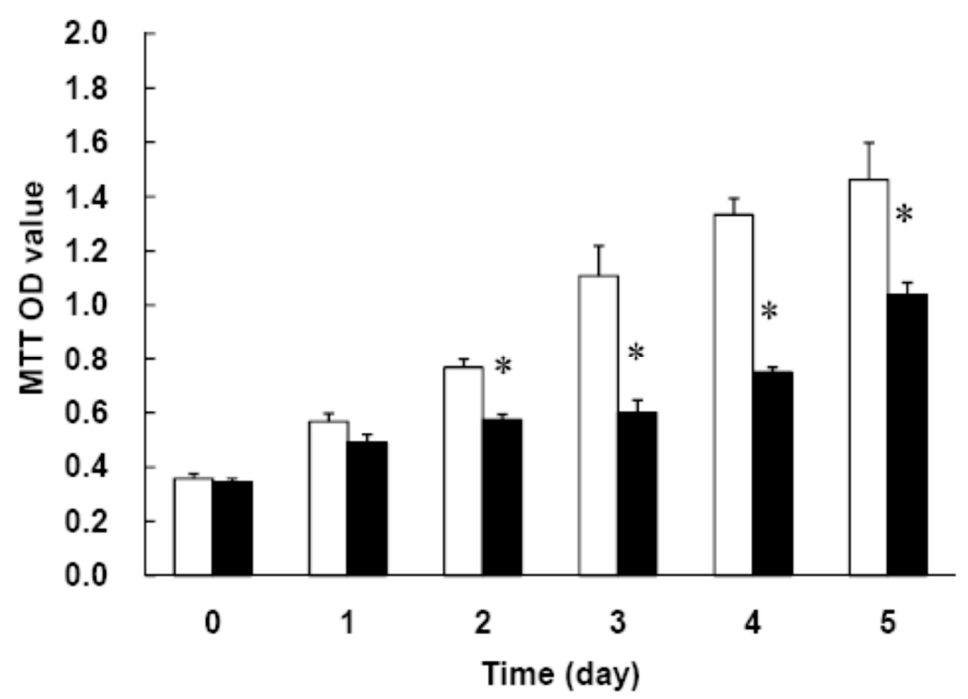

(B)

Figure 4. Low dose curcumin inhibits mitotic clonal expansion (MCE) during the early stage of adipocyte differentiation. 3T3-L1 preadipocytes were left untreated ( $\square$ ) or were pretreated with $15 \mu \mathrm{M}$ curcumin ( $\square)$ for $1 \mathrm{~h}$, then adipocyte differentiation was induced in the continued presence or absence of curcumin for 0-5 days, when MCE was measured by cell counting (A) or the MTT assay (B). The results are the mean $\pm \mathrm{SD}$ for four independent experiments. ${ }^{*} P<0.05$ compared to the vehicle control.

Table 2. Effect of $15 \mu \mathrm{M}$ curcumin on the cell cycle of 3T3-L1 preadipocytes.

\begin{tabular}{ccccc}
\hline \multirow{2}{*}{} & & \multicolumn{3}{c}{ Cell Cycle Distribution (\%) } \\
\cline { 3 - 5 } & & G0/G1 & S & G2/M \\
\hline \multirow{2}{*}{$0 \mathrm{~h}$} & Control & $75.25 \pm 3.73$ & $8.37 \pm 2.21$ & $15.86 \pm 2.16$ \\
& Curcumin & $75.21 \pm 4.87$ & $8.80 \pm 2.45$ & $15.57 \pm 2.75$ \\
\multirow{3}{*}{$4 \mathrm{~h}$} & Control & $47.10 \pm 9.72$ & $15.97 \pm 2.58$ & $35.08 \pm 9.79$ \\
& Curcumin & $68.25 \pm 4.68^{*}$ & $16.29 \pm 3.98$ & $14.86 \pm 3.05^{*}$ \\
\multirow{3}{*}{$72 \mathrm{~h}$} & Control & $77.52 \pm 3.73$ & $7.41 \pm 1.21$ & $14.21 \pm 1.07$ \\
& Curcumin & $42.37 \pm 9.76^{*}$ & $13.43 \pm 5.16$ & $39.09 \pm 9.06^{*}$ \\
& Control & $80.26 \pm 1.43$ & $7.31 \pm 0.62$ & $12.00 \pm 0.59$ \\
& Curcumin & $72.99 \pm 2.81^{*}$ & $8.70 \pm 2.44$ & $17.52 \pm 3.85^{*}$ \\
\hline \multirow{2}{*}{$* P<0.05$ compared to the control group. }
\end{tabular}

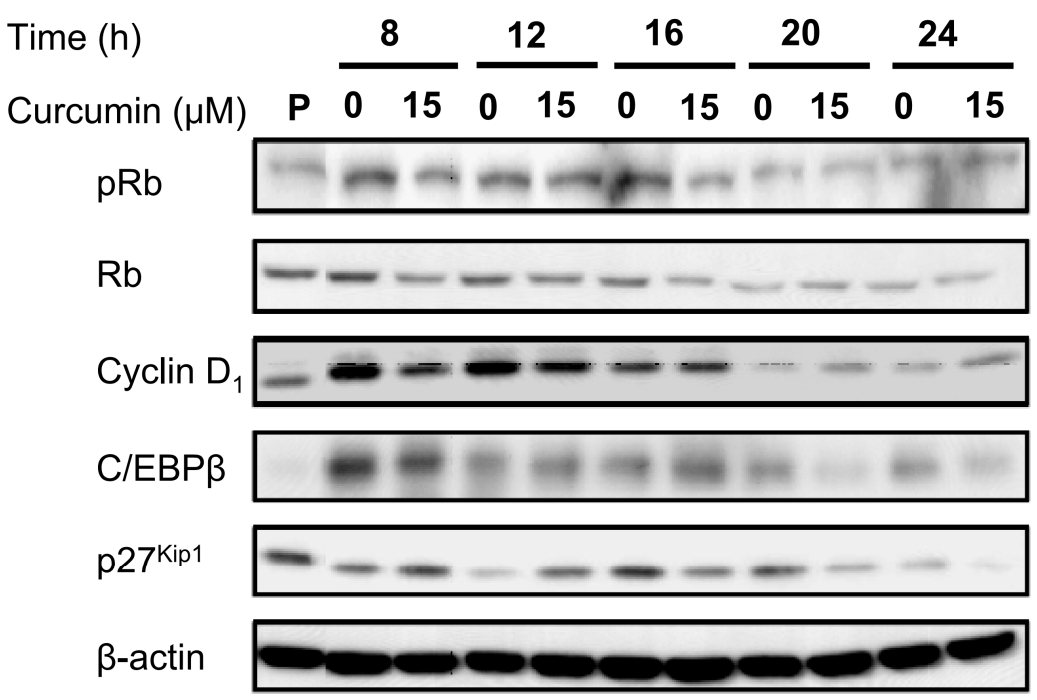

(A)

Figure 5. Cont. 


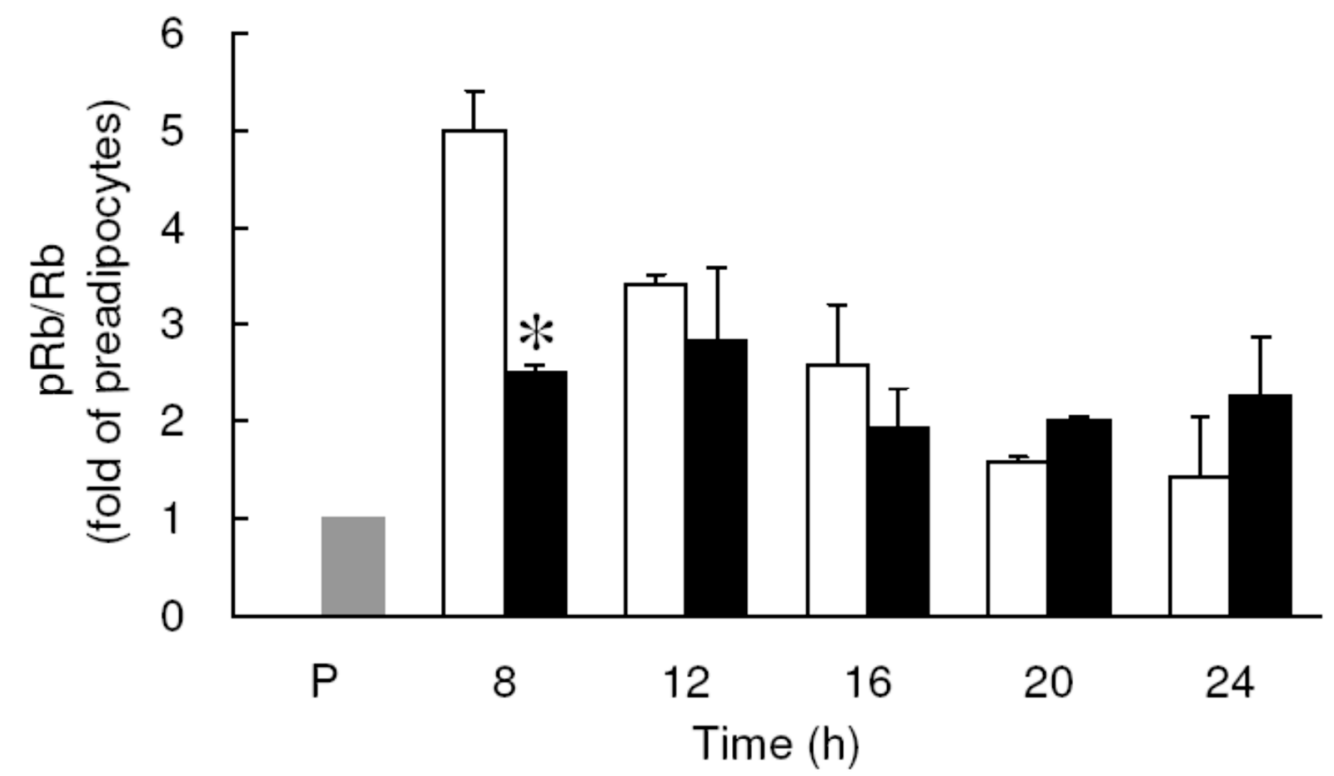

(B)

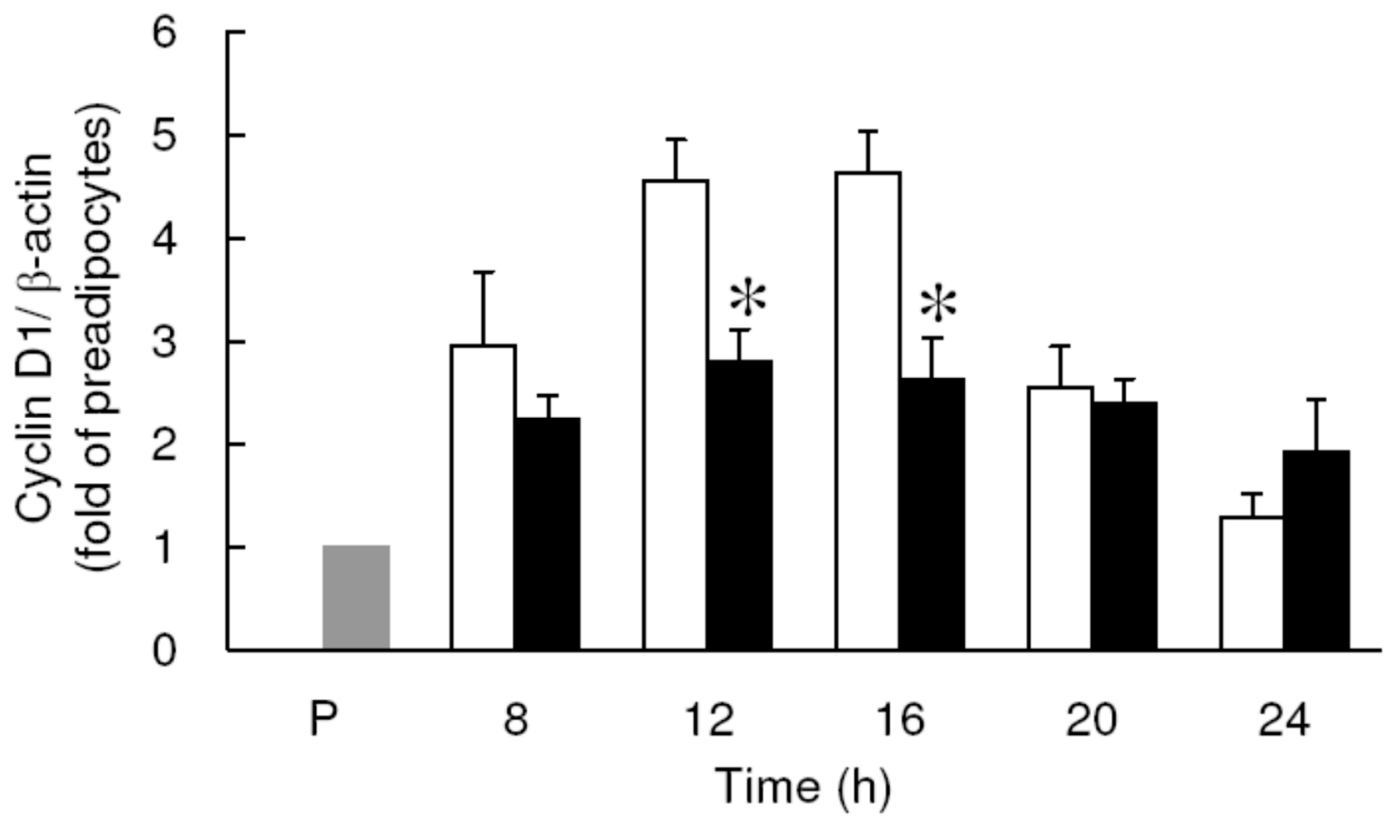

(C)

Figure 5. Cont. 


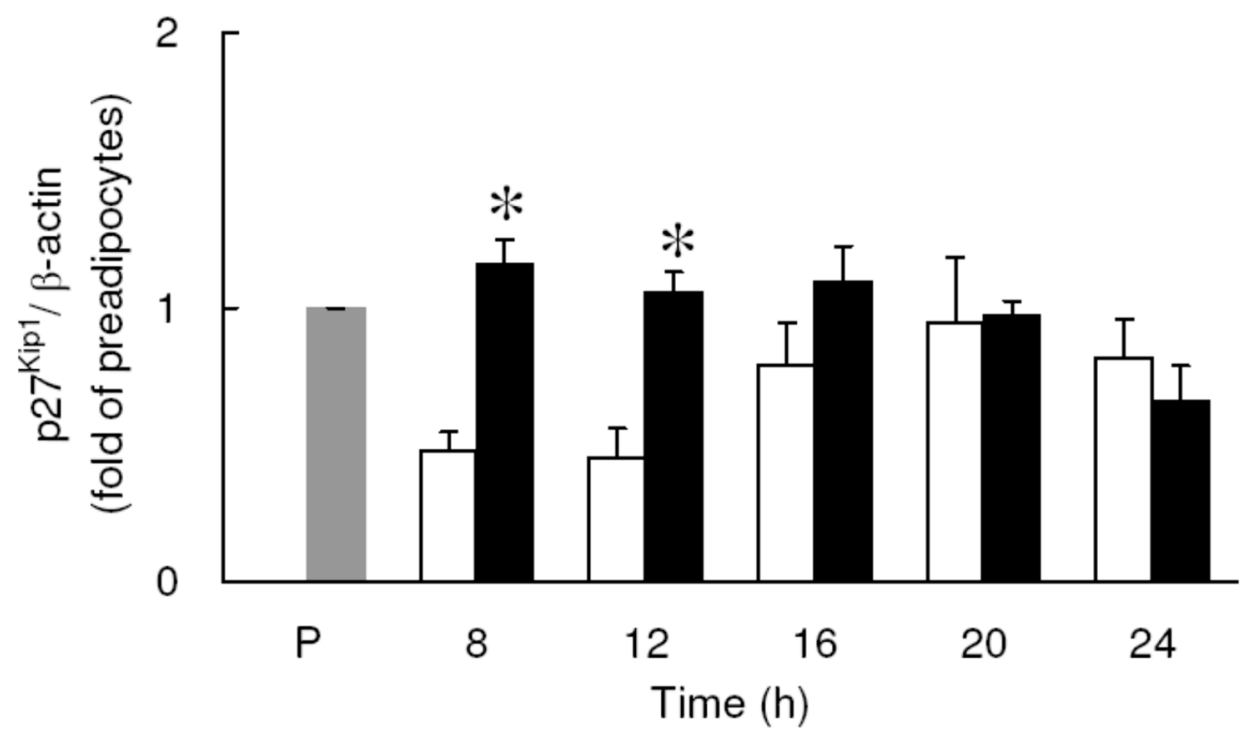

(D)

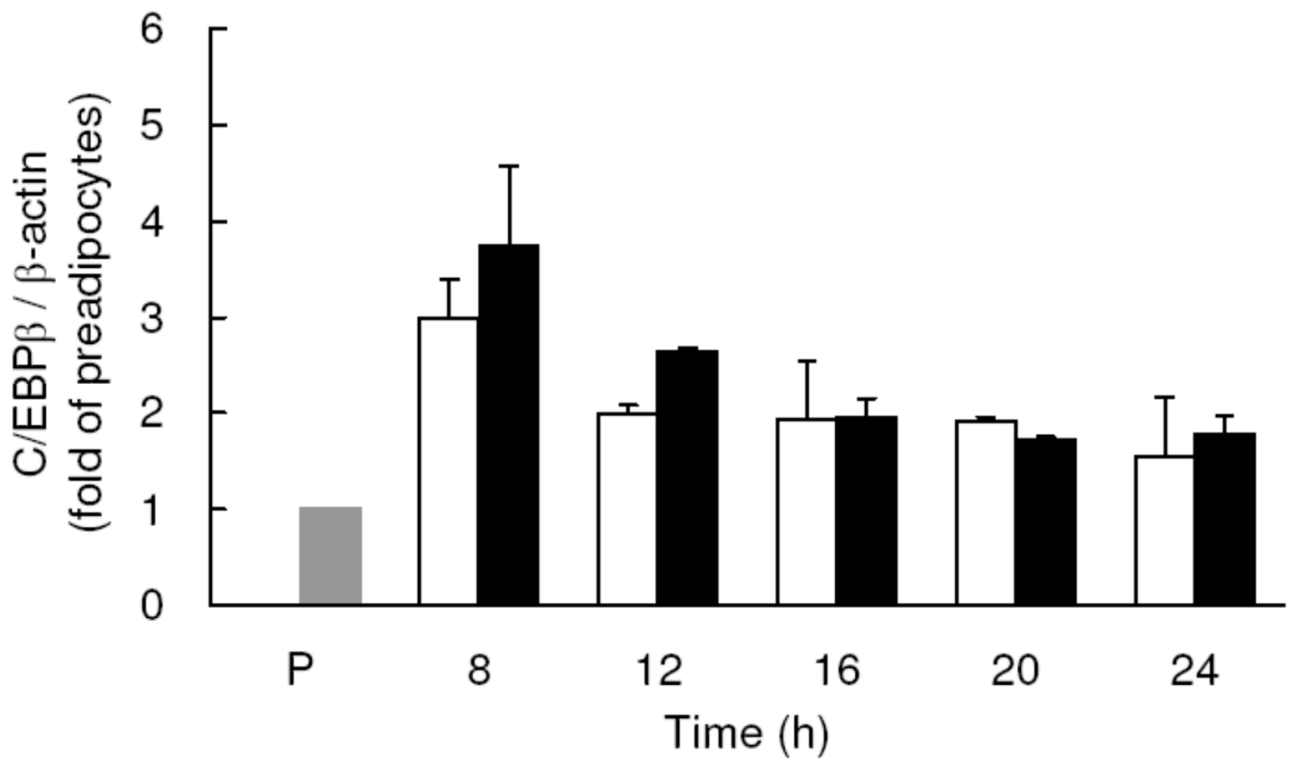

(E)

Figure 5. Low dose curcumin alters the expression or phosphorylation of cell cycle regulators during the early stage of adipocyte differentiation. 3T3-L1 preadipocytes were left untreated $(\square)$ or were pretreated with $15 \mu \mathrm{M}$ curcumin ( $\mathbf{\square})$ for $1 \mathrm{~h}$, then adipocyte differentiation was induced in the continued presence or absence of curcumin for 8-24 h, when $\mathrm{Rb}$ phosphorylation and expression of C/EBP $\beta$, cyclin $\mathrm{D}_{1}$, and $\mathrm{p} 27^{\mathrm{Kip} 1}$ were measured by immunoblotting. A representative blot is shown in (A) and the quantitative analysis of the results in (B-E). In (A), the results shown are representative of those in four separate experiments. In (B-E), the results are the mean \pm SD for four independent experiments. $\mathrm{P}$, preadipocytes; ${ }^{*} P<0.05$ compared to the vehicle control at the same time. 


\subsection{Effect of Low Dose Curcumin on Adipogenic Protein Expression in 3T3-L1 Cells During Differentiation}

We then explored the effect of low dose curcumin on the expression of the adipogenic transcription factors PPAR $\gamma, \mathrm{C} / \mathrm{EBP} \alpha$, and $\beta$-catenin. Compared to the levels in preadipocytes, expression of PPAR $\gamma$ (Figure 6A,B) and $\mathrm{C} / \mathrm{EBP} \alpha$ (Figure 6A,C) in untreated cells was significantly increased after $24 \mathrm{~h}$ and $48 \mathrm{~h}$ of induction of adipocyte differentiation, while expression of $\beta$-catenin was significantly decreased after $48 \mathrm{~h}$ of induction (Figure 6A,D). Furthermore, compared to the untreated controls, all three effects were completely or almost completely blocked by $15 \mu \mathrm{M}$ curcumin.

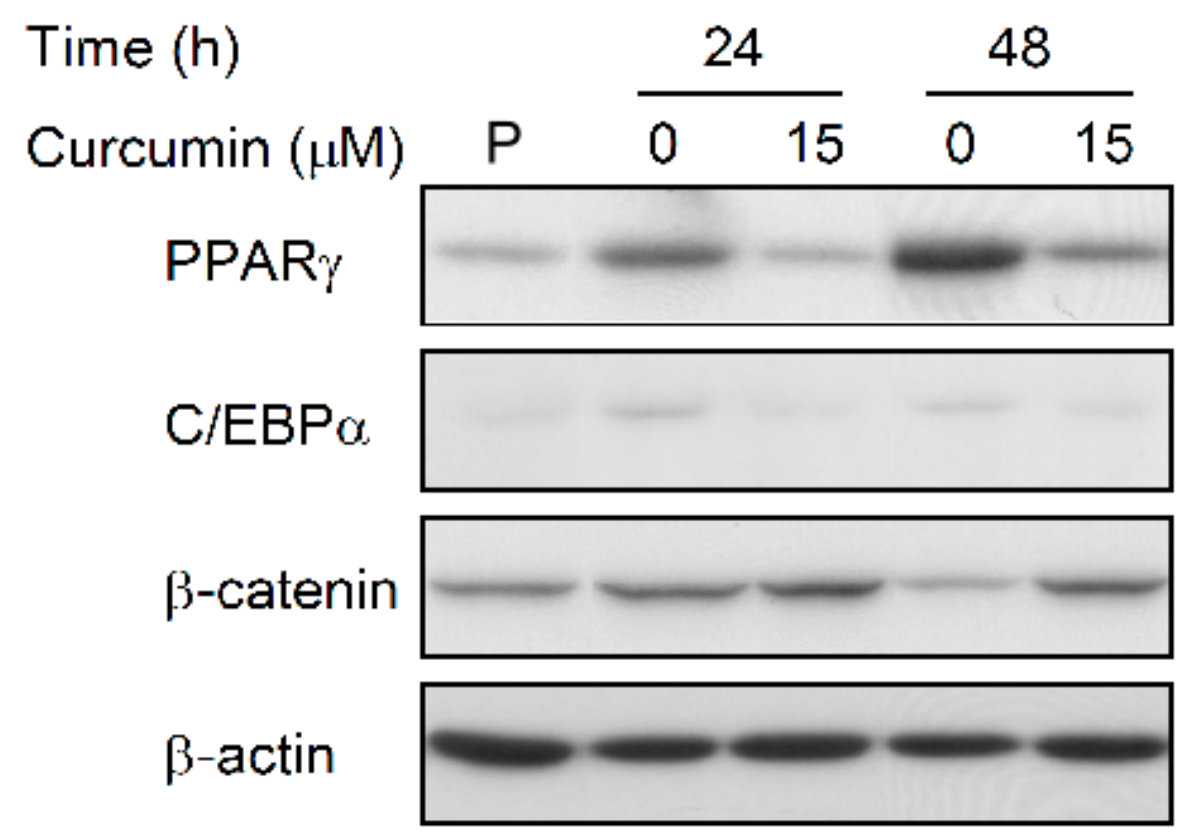

(A)

Figure 6. Cont. 


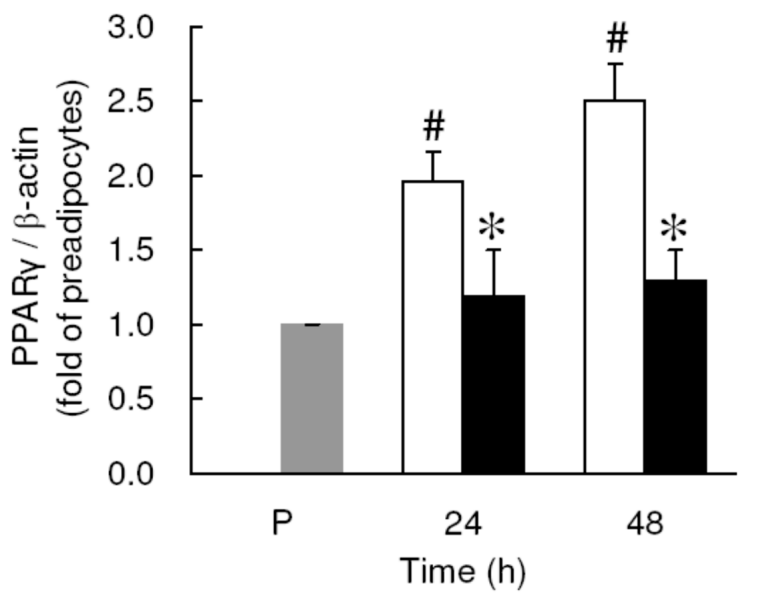

(B)

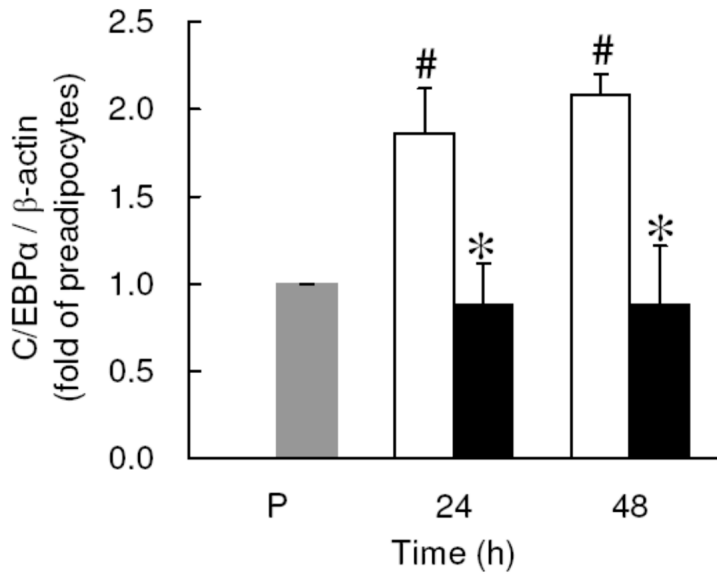

(C)

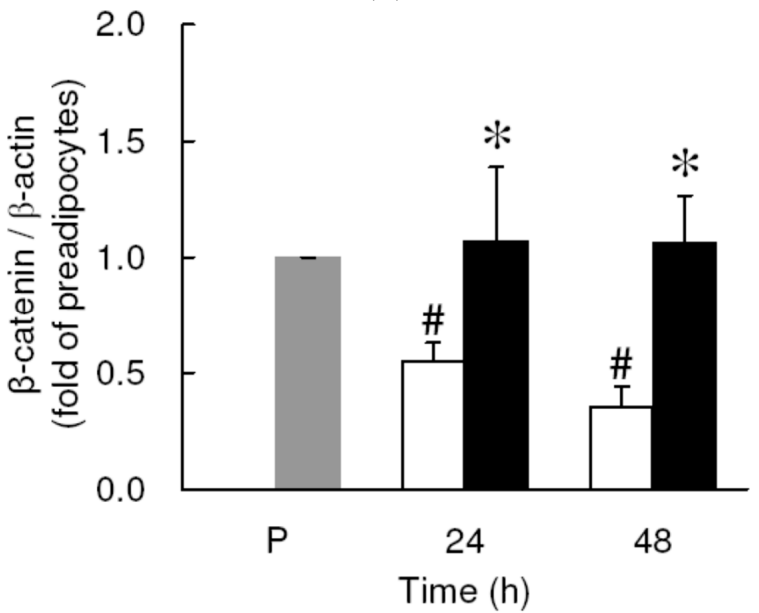

(D)

Figure 6. Low dose curcumin alters the expressions of adipogenic proteins during adipocyte differentiation. 3T3-L1 preadipocytes were incubated for $1 \mathrm{~h}$ with medium alone $(\square)$ or with $15-\mu \mathrm{M}$ curcumin ( $\mathbf{\square})$, then adipocyte differentiation was induced in the continued presence or absence of curcumin for 24 and $48 \mathrm{~h}$ and the expression of the adipogenic proteins PPAR $\gamma, \mathrm{C} / \mathrm{EBP} \alpha$, and $\beta$-catenin was measured by immunoblotting, with $\beta$-actin as the loading control. A representative blot is shown in $(\mathbf{A})$ and the quantitative analysis in (B-D). In (A), the results shown are representative of those in four separate experiments. In (B-D), the results are the mean \pm SD for four independent experiments. $\mathrm{P}$, preadipocytes; ${ }^{*} P<0.05$ compared to the vehicle control at the same time. ${ }^{\#} P<0.05$ compared to the preadipocytes. 


\subsection{Rosiglitazone Cannot Prevent the Curcumin-Induced Inhibition of Adipogenesis in 3T3-L1 Adipocytes}

We then explored whether administration of the PPAR $\gamma$ agonist rosiglitazone inhibited curcumin-inhibited adipogenesis. 3T3-L1 preadipocytes were incubated for $1 \mathrm{~h}$ with or without $0.5 \mu \mathrm{M}$ rosiglitazone, then were incubated for $1 \mathrm{~h}$ with or without $15 \mu \mathrm{M}$ curcumin in the continued presence or absence of rosiglitazone, and changes in MCE and efficiency of adipocytes differentiation was determined, respectively, by flow cytometry and measurement of the intracellular TG content. As shown in Figure 7A, rosiglitazone pretreatment failed to prevent curcumin-induced delayed G1/S phase entry and the subsequent G2/M phase transition in differentiating cells. However, as shown in Figure 7B, adipocyte lipid accumulation was significantly inhibited by curcumin treatment and significantly increased by rosiglitazone treatment, but rosiglitazone pretreatment only partially blocked curcumin-induced inhibition of adipogenesis.

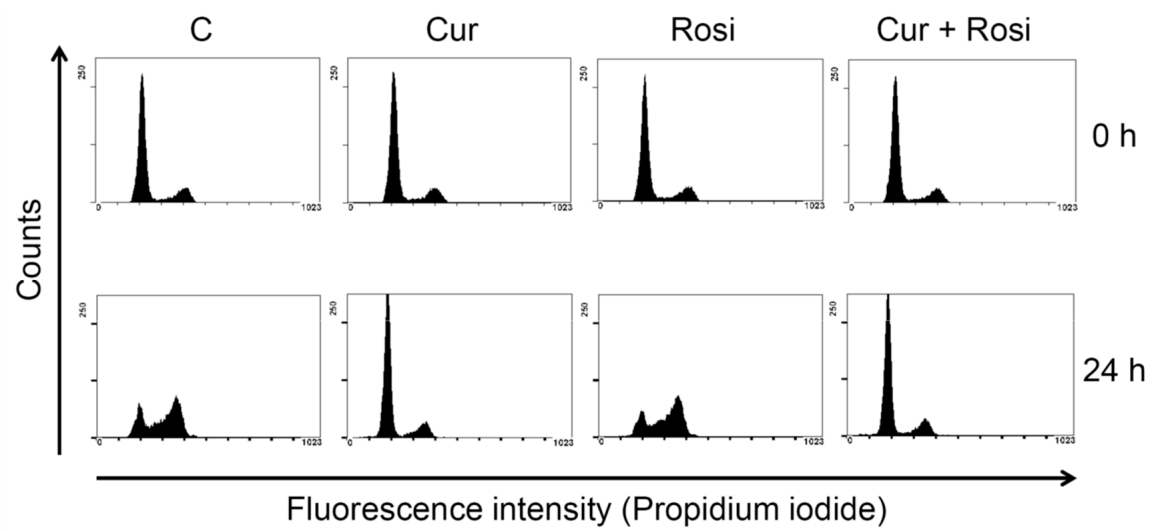

(A)

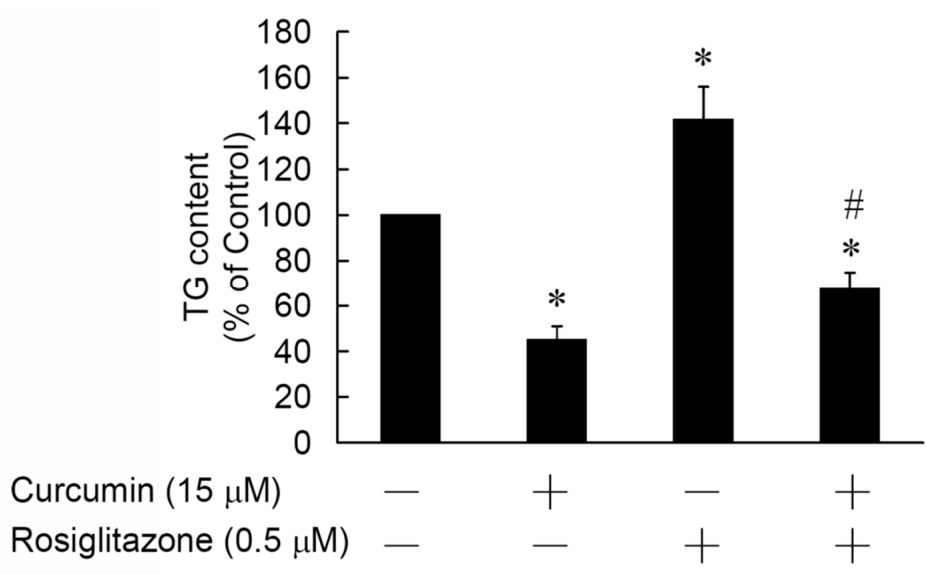

(B)

Figure 7. Lack of effect of rosiglitazone on the inhibitory effect of low dose curcumin on MCE and adipocyte differentiation. 3T3-L1 preadipocytes were incubated for $1 \mathrm{~h}$ with or without $0.5 \mu \mathrm{M}$ rosiglitazone, then for $1 \mathrm{~h}$ with or without $15 \mu \mathrm{M}$ curcumin in the continued presence or absence of rosiglitazone, and adipocyte differentiation was induced. During the differentiation processes, changes in MCE were examined at $24 \mathrm{~h}$ by flow cytometry (A) and changes in the efficiency of adipocyte differentiation were examined at 10 days by TG measurement (B). (A) is a representative plot of the MCE cytometric analyses from four independent experiments. In (B), the bar represents the mean \pm SD for four independent experiments. ${ }^{*} P<0.05$ compared to the vehicle control. ${ }^{\#} P<0.05$ compared to the rosiglitazone alone. 


\section{Discussion}

The main finding of this study is that curcumin induced preadipocyte apoptosis in a time- and dose-dependent manner and that this cytotoxic effect involved the activation of both the intrinsic and extrinsic apoptotic pathways. Several studies have demonstrated that curcumin induces apoptosis in different types of cancer cell [35-40]. These studies also demonstrated that curcumin induces cancer cell apoptosis through oxidative stress-, ER stress-, caspase cascade-, and mitochondria-dependent pathways. Our data are compatible with these studies. Besides, a recent study demonstrated that curcumin could induce apoptosis in SW872 human adipocytes [41]. Ferguson et al. observed an increasing apoptotic signaling at concentrations greater than $30 \mu \mathrm{M}$ [42]. Our data show that high dose curcumin induces apoptosis in 3T3-L1 preadipocytes (Figures 1 and 2). In addition, we found that curcumin activates caspase-8 in 3T3-L1 preadipocytes. Lee et al. and Wang et al. found that curcumin could promote Fas and Fas ligand expression in cancer cells [36,37]. Hence, it is possible that Fas/Fas ligand pathway may play a mechanistic role in curcumin-induced preadipocyte apoptosis. Many studies have demonstrated that curcumin suppresses adipocyte differentiation [13,15,43], but its effect on the viability of preadipocytes was not investigated in these studies. An important finding of this work was that curcumin-induced preadipocyte apoptosis could contribute to the inhibitory effect of curcumin on adipogenesis.

Another finding of the present study was that low dose curcumin delayed MCE during the early stage of adipocyte differentiation (Figure 4). The possible mechanism might involve the curcumin-induced downregulation of the early-response cell-cycle regulators phosphorylated $\mathrm{Rb}$ (pRb), cyclin D1, and p27 Kip1 (Figure 5A,C). Such curcumin-induced interference with cell-cycle regulator levels might cause the delayed $S$ phase entry and subsequent G2/M phase transition (Table 2 and Figure 1B) and lead to delayed MCE. Studies have demonstrated that MCE is necessary for adipocyte differentiation [19,21-23] and that the critical event for MCE is the transition from G1 phase to S phase [44]. Thus, delayed S phase entry may cause inhibition of MCE and lead to suppression of adipogenesis in 3T3-L1 adipocytes. Our findings are also in agreement with those of several studies which showed that delayed cell cycle entry of 3T3-L1 preadipocytes during the early stage of differentiation decreases MCE and reduces the differentiation efficiency of adipocytes [45-47]. Furthermore, we examined whether curcumin-inhibited adipogenesis was blocked by the addition of the PPAR $\gamma$ agonist rosiglitazone, which has been reported to directly bind and activate PPAR $\gamma$ and stimulate adipocyte differentiation [48,49]. Rosiglitazone partially blocked curcumin-suppressed lipid accumulation in 3T3-L1 adipocytes (Figure 7A), but had no effect on curcumin-induced delayed progression of MCE (Figure 7B). These results provide indirect support for the idea that impairment of MCE might lead to the inhibition of adipocyte differentiation.

Cell-cycle regulators, such as $\mathrm{Rb}$, cyclin $\mathrm{D} 1$, and $\mathrm{p} 27^{\mathrm{Kip} 1}$, play important roles in the $\mathrm{G} 1$ to $\mathrm{S}$ phase transition. In quiescent cells, there are low levels of cyclin D1 and high levels of p27 ${ }^{\text {Kip1 }}$, which associates with the cyclin E-Cdk2 complex and suppresses Cdk2 enzyme activity. Mitogenic stimulation (early G1 phase) induces the synthesis of cyclin D1, resulting in increased formation of the cyclin $\mathrm{D} / \mathrm{Cdk} 4$ complex, then $\mathrm{p} 27^{\mathrm{Kip} 1}$ dissociates from the cyclin E-Cdk2 complex and binds to the cyclin $\mathrm{D} / \mathrm{Cdk} 4$ complex and the Cdk2 activity is enhanced. Activated Cdk2 and Cdk4 phosphorylate Rb, $\mathrm{pRb}$ dissociates from E2F1, E2F1-dependent genes are expressed, and the cell cycle starts. Activated cyclin E-Cdk2 also phosphorylates p27 ${ }^{\text {Kip } 1}$, triggering its ubiquitination and degradation [50]. In the present study, the pattern of Rb phosphorylation and cyclin D1 and p27 ${ }^{\mathrm{Kip} 1}$ expression in the control cells matched those in control differentiating cells during the early stage of adipocyte differentiation reported previously [51]. However, treatment with $15 \mu \mathrm{M}$ curcumin significantly decreased $\mathrm{Rb}$ phosphorylation and cyclin D1 expression and increased the P27 ${ }^{\mathrm{Kip} 1}$ expression in the differentiating cells. Tian et al. also reported that treatment of curcumin could induce Rb mRNA upregulation in 3T3-L1 adipocytes [52]. These curcumin-induced changes in the expression profiles of cell cycle regulators might cause delayed G1/S phase transition and lead to the observed reduced MCE and suppressed adipocyte differentiation. Kim et al. [43] reported that curcumin modulates MCE by 
downregulating cyclin A and Cdk2 levels. During the G1/S phase transition, mitogenic stimulation induces cyclin D1 synthesis, followed sequentially by $\mathrm{Rb}$ phosphorylation and Cdk2 activation [50]. In our study, the curcumin-induced decrease in Rb phosphorylation and cyclin D1 expression and increase in P27 ${ }^{\text {Kip1 }}$ expression occurred earlier (G1 phase) than in Kim's study (S phase), but both studies suggest that curcumin interferes with MCE, then inhibits adipogenesis.

Phosphorylation of $\mathrm{Rb}$ is a major step in E2F1 activation, as $\mathrm{Rb}$ phosphorylation leads to $\mathrm{Rb}$ dissociation from transcription factor E2F1, triggering cell cycle progression [50,53]. Similar events occur during the early stage of adipogenesis [54]. A previous study demonstrated that E2F1 can regulate 3T3-L1 adipogenesis by binding directly to the PPAR $\gamma$ promoter and increasing expression of $\operatorname{PPAR} \gamma$, the master regulator of adipocyte differentiation [51]. In addition, a crosstalk between PPAR $\gamma$ and $\mathrm{Rb}$ signaling might operate during adipocyte differentiation, as a study has shown that $\mathrm{Rb}$ recruits histone deacetylase 3 (HDAC3) to PPAR $\gamma$ target genes and that disruption of the PPAR $\gamma$-Rb-HDAC3 complex by $\mathrm{Rb}$ phosphorylation or inhibition of HDAC3 activity results in activation of PPAR $\gamma$, translating as an increase in adipogenesis [55]. In addition, $\mathrm{pRb}$ has been shown to interact with the members of the C/EBP family, including C/EBP $\alpha$ and C/EBP $\beta[16,56]$. These findings indicate that $p R b$ plays a positive and direct role in the preadipocyte proliferation and terminal adipocyte differentiation.

In addition to the curcumin-induced downregulation of PPAR $\gamma$ and $C / E B P \alpha$, we also found that differentiation medium-induced downregulation of $\beta$-catenin was prevented by low dose curcumin treatment (Figure 6A,D). Previous studies has demonstrated that upregulation and activation of the Wnt/ $\beta$-catenin pathway in 3T3-L1 preadipocytes inhibits adipocyte differentiation $[32,33]$. In the present study, curcumin abolished the differentiation medium-induced downregulation or suppression of Wnt $/ \beta$-catenin signaling and this may contribute to the curcumin-induced inhibition on adipocyte differentiation. A very similar finding was reported by Ahn et al. [34], who demonstrated that curcumin stimulates the expression of $\mathrm{Wnt} / \beta$-catenin signaling components and targets in differentiating adipocytes. With the exception of the $\beta$-catenin expression results, our study and that of Ahn et al. both show that curcumin might suppress adipogenesis through modulation of $\mathrm{Wnt} / \beta$-catenin signaling.

Results of our present study are compatible with the findings of several studies, including curcumin inhibits adipocyte differentiation through modulation of MCE [43] and activation of Wnt/ $\beta$-catenin signaling [34,52]. In conclusion, the present study demonstrates that curcumin has dual effects on the regulation of adipogenesis (Figure 8). High dose curcumin induces preadipocyte apoptosis in a timeand dose-dependent manner through caspase 3- 8-, and 9-dependent pathways. In addition, low dose curcumin inhibits adipocyte differentiation by altering the expression of cell cycle regulators, reducing $\mathrm{MCE}$, downregulating expression of $\operatorname{PPAR} \gamma$ and $\mathrm{C} / \mathrm{EBP} \alpha$, preventing differentiation medium-induced $\beta$-catenin downregulation, and decreasing lipid accumulation. These findings suggest that curcumin supplementation could be an effective strategy for treating or preventing development of obesity by a curcumin-induced reduction in the number of preadipocytes and the fat mass of adipocytes. 


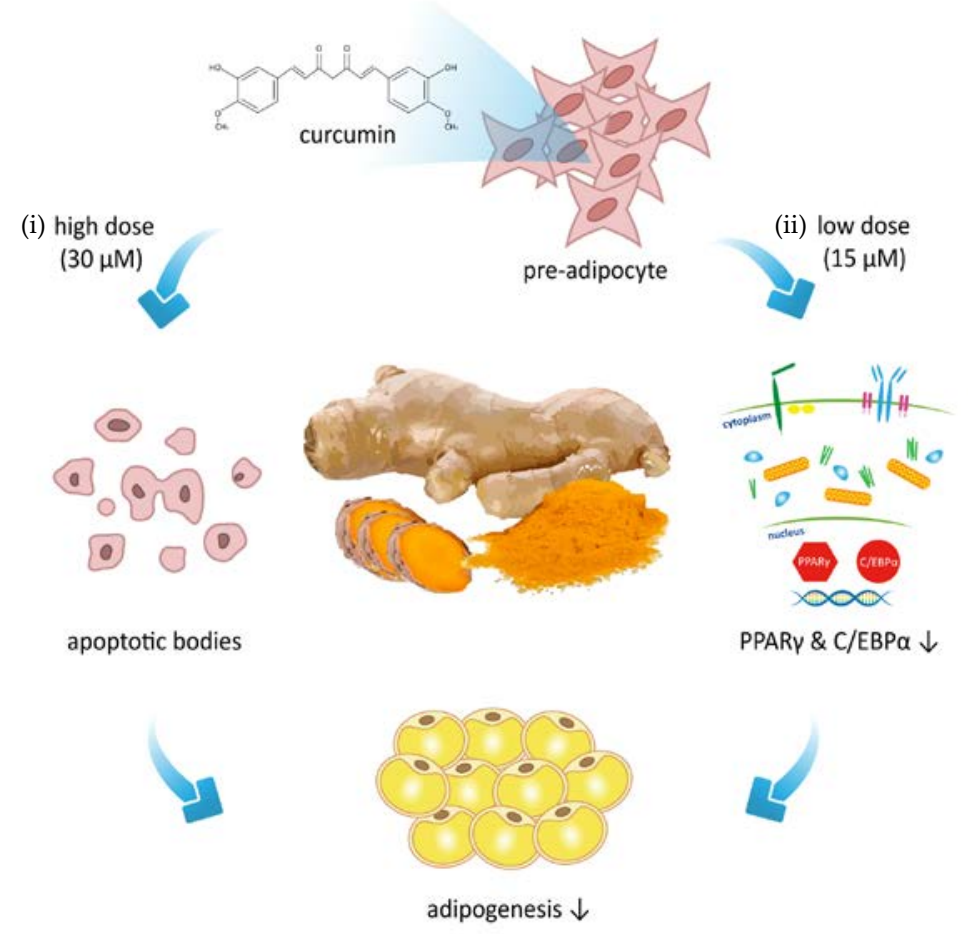

Figure 8. Schematic summary of the regulation of adipogenesis by curcumin in the 3T3-L1 adipocytes. Treatment of 3T3-L1 cells with curcumin has been found to attenuate the adipogenesis through (i) increased preadipocyte apoptosis, and (ii) diminished differentiation signaling protein (PPAR $\gamma$ and $\mathrm{C} / \mathrm{EBP} \alpha$ ) expression. Based on these observations, we identify the dual characteristics of curcumin on the suppression adipogenesis in 3T3-L1 adipocytes.

Author Contributions: L.-Y.W. and C.-W.C. conceived and designed the experiments as well as wrote the manuscript. L.-K.C., H.-Y.C., and C.-L.C. conducted experimental work, data analyses, and data interpretation. C.-C.J. conceptualized and designed the study, contributed to the interpretation of findings, drafted the initial manuscript, and approved the final manuscript.

Funding: This study was supported by research grants from the National Science Council of Taiwan (NSC98-2321-B-010-005; NSC99-2321-B-010-008), and "Yin Yen-Liang Foundation Development and Construction Plan" of the School of Medicine, National Yang-Ming University, Taipei, Taiwan.

Acknowledgments: The authors would like to acknowledge reviewers for providing constructive suggestions.

Conflicts of Interest: The authors declare no conflict of interest.

\section{Abbreviations}

$\begin{array}{ll}\text { AMPK } & \text { AMP-activated protein kinase } \\ \text { Cdk2 } & \text { cyclin-dependent kinase 2 } \\ \text { C/EBPs } & \text { CCAAT enhancer binding proteins } \\ \text { HDAC3 } & \text { histone deacetylase 3 } \\ \text { IBMX } & \text { isobutylmethylxanthine } \\ \text { MCE } & \text { mitotic clonal expansion } \\ \text { MTT } & \text { 3-(4,5-dimethylthiazol-2-yl)- 2,5-diphenyltetrazolium bromide } \\ \text { PPARs } & \text { peroxisome proliferator-activated receptors } \\ \text { Rb } & \text { retinoblastoma protein } \\ \text { TUNEL } & \text { terminal deoxynucleotidyl transferase dUTP nick end labeling }\end{array}$




\section{References}

1. Mathieu, P.; Lemieux, I.; Despres, J.P. Obesity, inflammation, and cardiovascular risk. Clin. Pharmacol. Ther. 2010, 87, 407-416. [CrossRef] [PubMed]

2. Weihrauch-Bluher, S.; Schwarz, P.; Klusmann, J.H. Childhood obesity: Increased risk for cardiometabolic disease and cancer in adulthood. Metabolism 2019, 92, 147-152. [CrossRef] [PubMed]

3. Padwal, R.S.; Sharma, A.M. Prevention of cardiovascular disease: Obesity, diabetes and the metabolic syndrome. Can. J. Cardiol. 2010, 26, 18C-20C. [CrossRef]

4. Wyne, K.L. Preventing cardiovascular disease and diabetes: A call to action from the ADA and AHA. J. Cardiometab. Syndr. 2006, 1, 220-221. [CrossRef] [PubMed]

5. Wafi, A.M.; Hong, J.; Rudebush, T.L.; Yu, L.; Hackfort, B.; Wang, H.; Schultz, H.D.; Zucker, I.H.; Gao, L. Curcumin improves exercise performance of mice with coronary artery ligation-induced HFrEF: Nrf2 and antioxidant mechanisms in skeletal muscle. J. Appl. Physiol. 2019, 126, 477-486. [CrossRef] [PubMed]

6. Ikram, M.; Saeed, K.; Khan, A.; Muhammad, T.; Khan, M.S.; Jo, M.G.; Rehman, S.U.; Kim, M.O. Natural dietary supplementation of curcumin protects mice brains against ethanol-induced oxidative stress-mediated neurodegeneration and memory impairment via Nrf2/TLR4/RAGE signaling. Nutrients 2019, 11, 1082. [CrossRef]

7. Lin, C.C.; Chiang, T.H.; Sun, Y.Y.; Lin, M.S. Protective effects of CISD2 and influence of curcumin on CISD2 expression in aged animals and inflammatory cell model. Nutrients 2019, 11, 700. [CrossRef]

8. Adams, B.K.; Ferstl, E.M.; Davis, M.C.; Herold, M.; Kurtkaya, S.; Camalier, R.F.; Hollingshead, M.G.; Kaur, G.; Sausville, E.A.; Rickles, F.R.; et al. Synthesis and biological evaluation of novel curcumin analogs as anti-cancer and anti-angiogenesis agents. Bioorg. Med. Chem. 2004, 12, 3871-3883. [CrossRef] [PubMed]

9. Mirzaei, H.; Masoudifar, A.; Sahebkar, A.; Zare, N.; Sadri Nahand, J.; Rashidi, B.; Mehrabian, E.; Mohammadi, M.; Mirzaei, H.R.; Jaafari, M.R. MicroRNA: A novel target of curcumin in cancer therapy. J. Cell. Physiol. 2018, 233, 3004-3015. [CrossRef]

10. Gonzales, A.M.; Orlando, R.A. Curcumin and resveratrol inhibit nuclear factor-kB-mediated cytokine expression in adipocytes. Nutr. Metab. 2008, 5, 17. [CrossRef]

11. Nishiyama, T.; Mae, T.; Kishida, H.; Tsukagawa, M.; Mimaki, Y.; Kuroda, M.; Sashida, Y.; Takahashi, K.; Kawada, T.; Nakagawa, K.; et al. Curcuminoids and sesquiterpenoids in turmeric (Curcuma longa L.) suppress an increase in blood glucose level in type 2 diabetic KK-Ay mice. J. Agric. Food Chem. 2005, 53, 959-963. [CrossRef] [PubMed]

12. Weisberg, S.P.; Leibel, R.; Tortoriello, D.V. Dietary curcumin significantly improves obesity-associated inflammation and diabetes in mouse models of diabesity. Endocrinology 2008, 149, 3549-3558. [CrossRef] [PubMed]

13. Ejaz, A.; Wu, D.; Kwan, P.; Meydani, M. Curcumin inhibits adipogenesis in 3T3-L1 adipocytes and angiogenesis and obesity in C57/BL mice. J. Nutr. 2009, 139, 919-925. [CrossRef] [PubMed]

14. Ding, L.; Li, J.; Song, B.; Xiao, X.; Zhang, B.; Qi, M.; Huang, W.; Yang, L.; Wang, Z. Curcumin rescues high fat diet-induced obesity and insulin sensitivity in mice through regulating SREBP pathway. Toxicol. Appl. Pharmacol. 2016, 304, 99-109. [CrossRef] [PubMed]

15. Lee, Y.K.; Lee, W.S.; Hwang, J.T.; Kwon, D.Y.; Surh, Y.J.; Park, O.J. Curcumin exerts antidifferentiation effect through AMPK $\alpha$-PPAR- $\gamma$ in 3T3-L1 adipocytes and antiproliferatory effect through AMPK $\alpha$-COX-2 in cancer cells. J. Agric. Food Chem. 2009, 57, 305-310. [CrossRef] [PubMed]

16. Chen, P.L.; Riley, D.J.; Chen, Y.; Lee, W.H. Retinoblastoma protein positively regulates terminal adipocyte differentiation through direct interaction with C/EBPs. Genes Dev. 1996, 10, 2794-2804. [CrossRef]

17. Hansen, J.B.; Petersen, R.K.; Larsen, B.M.; Bartkova, J.; Alsner, J.; Kristiansen, K. Activation of peroxisome proliferator-activated receptor gamma bypasses the function of the retinoblastoma protein in adipocyte differentiation. J. Biol. Chem. 1999, 274, 2386-2393. [CrossRef]

18. Hiebert, S.W.; Chellappan, S.P.; Horowitz, J.M.; Nevins, J.R. The interaction of RB with E2F coincides with an inhibition of the transcriptional activity of E2F. Genes Dev. 1992, 6, 177-185. [CrossRef]

19. Fajas, L. Adipogenesis: A cross-talk between cell proliferation and cell differentiation. Ann. Med. 2003, 35, 79-85. [CrossRef] 
20. Kobayashi, M.; Ohsugi, M.; Sasako, T.; Awazawa, M.; Umehara, T.; Iwane, A.; Kobayashi, N.; Okazaki, Y.; Kubota, N.; Suzuki, R.; et al. The RNA methyltransferase complex of WTAP, METTL3, and METTL14 regulates mitotic clonal expansion in adipogenesis. Mol. Cell. Biol. 2018, 38. [CrossRef]

21. Otto, T.C.; Lane, M.D. Adipose development: From stem cell to adipocyte. Crit. Rev. Biochem. Mol. Biol. 2005, 40, 229-242. [CrossRef] [PubMed]

22. Tang, Q.Q.; Otto, T.C.; Lane, M.D. Mitotic clonal expansion: A synchronous process required for adipogenesis. Proc. Natl. Acad. Sci. USA 2003, 100, 44-49. [CrossRef] [PubMed]

23. Yeh, W.C.; Bierer, B.E.; McKnight, S.L. Rapamycin inhibits clonal expansion and adipogenic differentiation of 3T3-L1 cells. Proc. Natl. Acad. Sci. USA 1995, 92, 11086-11090. [CrossRef] [PubMed]

24. de Melo, K.M.; de Oliveira, F.T.B.; Costa Silva, R.A.; Gomes Quindere, A.L.; Marinho Filho, J.D.B.; Araujo, A.J.; Barros Pereira, E.D.; Carvalho, A.A.; Chaves, M.H.; Rao, V.S.; et al. $\alpha, \beta$-Amyrin, a pentacyclic triterpenoid from Protium heptaphyllum suppresses adipocyte differentiation accompanied by down regulation of PPAR $\gamma$ and C/EBP $\alpha$ in 3T3-L1 cells. Biomed. Pharmacother. 2019, 109, 1860-1866. [CrossRef] [PubMed]

25. Park, M.; Sharma, A.; Lee, H.J. Anti-adipogenic effects of delphinidin-3-O-beta-glucoside in 3T3-L1 preadipocytes and primary white adipocytes. Molecules 2019, 24, 1848. [CrossRef]

26. Darlington, G.J.; Ross, S.E.; MacDougald, O.A. The role of C/EBP genes in adipocyte differentiation. J. Biol. Chem. 1998, 273, 30057-30060. [CrossRef]

27. Yeh, W.C.; Cao, Z.; Classon, M.; McKnight, S.L. Cascade regulation of terminal adipocyte differentiation by three members of the C/EBP family of leucine zipper proteins. Genes Dev. 1995, 9, 168-181. [CrossRef]

28. Wu, Z.; Bucher, N.L.; Farmer, S.R. Induction of peroxisome proliferator-activated receptor gamma during the conversion of $3 \mathrm{~T} 3$ fibroblasts into adipocytes is mediated by $\mathrm{C} / \mathrm{EBP} \beta, \mathrm{C} / \mathrm{EBP} \delta$, and glucocorticoids. Mol. Cell. Biol. 1996, 16, 4128-4136. [CrossRef]

29. Zhang, J.W.; Tang, Q.Q.; Vinson, C.; Lane, M.D. Dominant-negative C/EBP disrupts mitotic clonal expansion and differentiation of 3T3-L1 preadipocytes. Proc. Natl. Acad. Sci. USA 2004, 101, 43-47. [CrossRef]

30. Rosen, E.D.; Hsu, C.H.; Wang, X.; Sakai, S.; Freeman, M.W.; Gonzalez, F.J.; Spiegelman, B.M. C/EBPalpha induces adipogenesis through PPAR $\gamma$ : A unified pathway. Genes Dev. 2002, 16, 22-26. [CrossRef]

31. Shao, D.; Lazar, M.A. Peroxisome proliferator activated receptor gamma, CCAAT/enhancer-binding protein alpha, and cell cycle status regulate the commitment to adipocyte differentiation. J. Biol. Chem. 1997, 272, 21473-21478. [CrossRef] [PubMed]

32. Christodoulides, C.; Lagathu, C.; Sethi, J.K.; Vidal-Puig, A. Adipogenesis and WNT signalling. Trends Endocrinol. Metab. 2009, 20, 16-24. [CrossRef] [PubMed]

33. Ross, S.E.; Hemati, N.; Longo, K.A.; Bennett, C.N.; Lucas, P.C.; Erickson, R.L.; MacDougald, O.A. Inhibition of adipogenesis by Wnt signaling. Science 2000, 289, 950-953. [CrossRef] [PubMed]

34. Ahn, J.; Lee, H.; Kim, S.; Ha, T. Curcumin-induced suppression of adipogenic differentiation is accompanied by activation of Wnt/ $\beta$-catenin signaling. Am. J. Physiol. Cell Physiol. 2010, 298, C1510-C1516. [CrossRef]

35. Ibrahim, A.; El-Meligy, A.; Lungu, G.; Fetaih, H.; Dessouki, A.; Stoica, G.; Barhoumi, R. Curcumin induces apoptosis in a murine mammary gland adenocarcinoma cell line through the mitochondrial pathway. Eur. J. Pharmacol. 2011, 668, 127-132. [CrossRef] [PubMed]

36. Lee, H.P.; Li, T.M.; Tsao, J.Y.; Fong, Y.C.; Tang, C.H. Curcumin induces cell apoptosis in human chondrosarcoma through extrinsic death receptor pathway. Int. Immunopharmacol. 2012, 13, 163-169. [CrossRef] [PubMed]

37. Wang, W.Z.; Li, L.; Liu, M.Y.; Jin, X.B.; Mao, J.W.; Pu, Q.H.; Meng, M.J.; Chen, X.G.; Zhu, J.Y. Curcumin induces FasL-related apoptosis through p38 activation in human hepatocellular carcinoma Huh7 cells. Life Sci. 2013, 92, 352-358. [CrossRef]

38. Yang, C.L.; Ma, Y.G.; Xue, Y.X.; Liu, Y.Y.; Xie, H.; Qiu, G.R. Curcumin induces small cell lung cancer NCI-H446 cell apoptosis via the reactive oxygen species-mediated mitochondrial pathway and not the cell death receptor pathway. DNA Cell Biol. 2012, 31, 139-150. [CrossRef]

39. Agarwal, A.; Kasinathan, A.; Ganesan, R.; Balasubramanian, A.; Bhaskaran, J.; Suresh, S.; Srinivasan, R.; Aravind, K.B.; Sivalingam, N. Curcumin induces apoptosis and cell cycle arrest via the activation of reactive oxygen species-independent mitochondrial apoptotic pathway in Smad4 and p53 mutated colon adenocarcinoma HT29 cells. Nutr. Res. 2018, 51, 67-81. [CrossRef]

40. Fu, H.; Wang, C.; Yang, D.; Wei, Z.; Xu, J.; Hu, Z.; Zhang, Y.; Wang, W.; Yan, R.; Cai, Q. Curcumin regulates proliferation, autophagy, and apoptosis in gastric cancer cells by affecting PI3K and P53 signaling. J. Cell. Physiol. 2018, 233, 4634-4642. [CrossRef] 
41. Zhu, L.; Han, M.B.; Gao, Y.; Wang, H.; Dai, L.; Wen, Y.; Na, L.X. Curcumin triggers apoptosis via upregulation of Bax/Bcl-2 ratio and caspase activation in SW872 human adipocytes. Mol. Med. Rep. 2015, 12, 1151-1156. [CrossRef] [PubMed]

42. Ferguson, B.S.; Nam, H.; Morrison, R.F. Curcumin Inhibits 3T3-L1 Preadipocyte proliferation by mechanisms involving post-transcriptional p27 regulation. Biochem. Biophys. Rep. 2016, 5, 16-21. [CrossRef] [PubMed]

43. Kim, C.Y.; Le, T.T.; Chen, C.; Cheng, J.X.; Kim, K.H. Curcumin inhibits adipocyte differentiation through modulation of mitotic clonal expansion. J. Nutr. Biochem. 2011, 22, 910-920. [CrossRef] [PubMed]

44. Zhang, Y.Y.; Li, X.; Qian, S.W.; Guo, L.; Huang, H.Y.; He, Q.; Liu, Y.; Ma, C.G.; Tang, Q.Q. Transcriptional activation of histone $\mathrm{H} 4$ by $\mathrm{C} / \mathrm{EBP} \beta$ during the mitotic clonal expansion of 3T3-L1 adipocyte differentiation. Mol. Biol. Cell 2011, 22, 2165-2174. [CrossRef] [PubMed]

45. Drira, R.; Chen, S.; Sakamoto, K. Oleuropein and hydroxytyrosol inhibit adipocyte differentiation in 3 T3-L1 cells. Life Sci. 2011, 89, 708-716. [CrossRef] [PubMed]

46. Findeisen, H.M.; Pearson, K.J.; Gizard, F.; Zhao, Y.; Qing, H.; Jones, K.L.; Cohn, D.; Heywood, E.B.; de Cabo, R.; Bruemmer, D. Oxidative stress accumulates in adipose tissue during aging and inhibits adipogenesis. PLoS ONE 2011, 6, e18532. [CrossRef]

47. Kim, S.H.; Park, H.S.; Lee, M.S.; Cho, Y.J.; Kim, Y.S.; Hwang, J.T.; Sung, M.J.; Kim, M.S.; Kwon, D.Y. Vitisin A inhibits adipocyte differentiation through cell cycle arrest in 3T3-L1 cells. Biochem. Biophys. Res. Commun. 2008, 372, 108-113. [CrossRef]

48. Rhee, S.D.; Sung, Y.Y.; Jung, W.H.; Cheon, H.G. Leptin inhibits rosiglitazone-induced adipogenesis in murine primary adipocytes. Mol. Cell. Endocrinol. 2008, 294, 61-69. [CrossRef]

49. Zhang, X.; Chen, X.; Qi, T.; Kong, Q.; Cheng, H.; Cao, X.; Li, Y.; Li, C.; Liu, L.; Ding, Z. HSPA12A is required for adipocyte differentiation and diet-induced obesity through a positive feedback regulation with PPAR $\gamma$. Cell Death Differ. 2019. [CrossRef]

50. Sherr, C.J.; McCormick, F. The RB and p53 pathways in cancer. Cancer Cell 2002, 2, 103-112. [CrossRef]

51. Cole, K.A.; Harmon, A.W.; Harp, J.B.; Patel, Y.M. Rb regulates C/EBP $\beta$-DNA-binding activity during 3T3-L1 adipogenesis. Am. J. Physiol. Cell Physiol. 2004, 286, C349-C354. [CrossRef] [PubMed]

52. Tian, L.; Song, Z.; Shao, W.; Du, W.W.; Zhao, L.R.; Zeng, K.; Yang, B.B.; Jin, T. Curcumin represses mouse 3T3-L1 cell adipogenic differentiation via inhibiting miR-17-5p and stimulating the Wnt signalling pathway effector Tcf712. Cell Death Dis. 2017, 8, e2559. [CrossRef] [PubMed]

53. Aguilar, V.; Fajas, L. Cycling through metabolism. EMBO Mol. Med. 2010, 2, 338-348. [CrossRef] [PubMed]

54. Richon, V.M.; Lyle, R.E.; McGehee, R.E., Jr. Regulation and expression of retinoblastoma proteins p107 and p130 during 3T3-L1 adipocyte differentiation. J. Biol. Chem. 1997, 272, 10117-10124. [CrossRef] [PubMed]

55. Fajas, L.; Egler, V.; Reiter, R.; Hansen, J.; Kristiansen, K.; Debril, M.B.; Miard, S.; Auwerx, J. The retinoblastoma-histone deacetylase 3 complex inhibits PPAR $\gamma$ and adipocyte differentiation. Dev. Cell 2002, 3, 903-910. [CrossRef]

56. Charles, A.; Tang, X.; Crouch, E.; Brody, J.S.; Xiao, Z.X. Retinoblastoma protein complexes with C/EBP proteins and activates C/EBP-mediated transcription. J. Cell. Biochem. 2001, 83, 414-425. [CrossRef] [PubMed] 